TITLE:

\title{
An Annotated List of Blenniid Fishes from Shirahama, Wakayama Prefecture, Japan
}

$\operatorname{AUTHOR}(\mathrm{S})$ :

Fukao, Ryuzo

CITATION:

Fukao, Ryuzo. An Annotated List of Blenniid Fishes from Shirahama, Wakayama

Prefecture, Japan. PUBLICATIONS OF THE SETO MARINE BIOLOGICAL LABORATORY 1985, 30(1-3): 81-124

ISSUE DATE:

1985-06-30

URL:

http://hdl.handle.net/2433/176099

RIGHT: 


\title{
An Annotated List of Blenniid Fishes from Shirahama, Wakayama Prefecture, Japan
}

\author{
By \\ Ryuzo Fukao \\ The Institute of Environmental Toxicology, 4321 Uchimoriya, \\ Mitsukaido-shi, Ibaraki, 302-02, Japan
}

With Text-figures $1-28$ and Tables 1-20

During the years from 1972 to 1979 , observations have been made on blenniid fishes in the waters of Shirahama on the Pacific coast of Honshu, the main island of Japan. The blenniid species observed and/or collected during the study period were listed, with comments on some aspects of their ecology and morphology. An estimation was also made on the degree of establishment in the population of each species in the study area, located at the peripheral in the distribution of the family Blenniidae.

Thirty-two species including subspecies, about the half of 66 blenniid species validly reported from Japan, were observed and 26 species or subspecies were collected in the present study. Among the species observed, 10 species have already been included in the list of Araga \& Tanase (1966). Besides these 10 species, a species, Cirripectes kuwamurai (as Cirripectes sp.), two species, Exallias brevis and Cirripectes polyzona (as C. sebae), two species, Aspidontus dussumieri and Plagiotremus laudandus and three species of Cirripectes have already been reported by Masuda et al. (1975, 1980), Kuwamura (1976), Kuwamura (1981), and Fukao (1984), respectively.

\section{Study Area, Materials and Methods}

The study area is located at approximately $33^{\circ} 4.1^{\prime} \mathrm{N}$ and $135^{\circ} 20^{\prime} \mathrm{E}$, and occupies the whole southern coast of Tanabe Bay on the west coast of Kii Peninsula (Fig. 1). The area is climatically warm temperate, washed by a branch of the warm Kuroshio Current and has a rich fish fauna (Araga \& Tanase, 1966). The water temperatures rise up nearly $30^{\circ} \mathrm{C}$ in mid-summer and ordinarily fall down to about $12^{\circ} \mathrm{C}$ in mid-winter (sometimes down to under $10^{\circ} \mathrm{C}$ in hard winter). Topographical features of the area are complicated with mixtures of rock, pebble, sand, and mud substrata, on which sometimes carrying variously sized boulders. Colonies of corals are commonly found on moderately to very exposed rocky reefs.

Underwater observations were made using SCUBA or by snorkelling. At low tide, occasionally, observations were made in tide pools. Intensity of observations was not constant among sites and among seasons. Moderately to very exposed rocky reefs around the Seto Marine Biological Laboratory located at the Bansho Point were intensively investigated, whereas the sheltered inner part of Tanabe Bay were investigated only several times. Observations were concentrated during the

Publ. Seto Mar. Biol. Lab., 30 (1/3), 81-124, $1985 \quad$ (Article 4) 


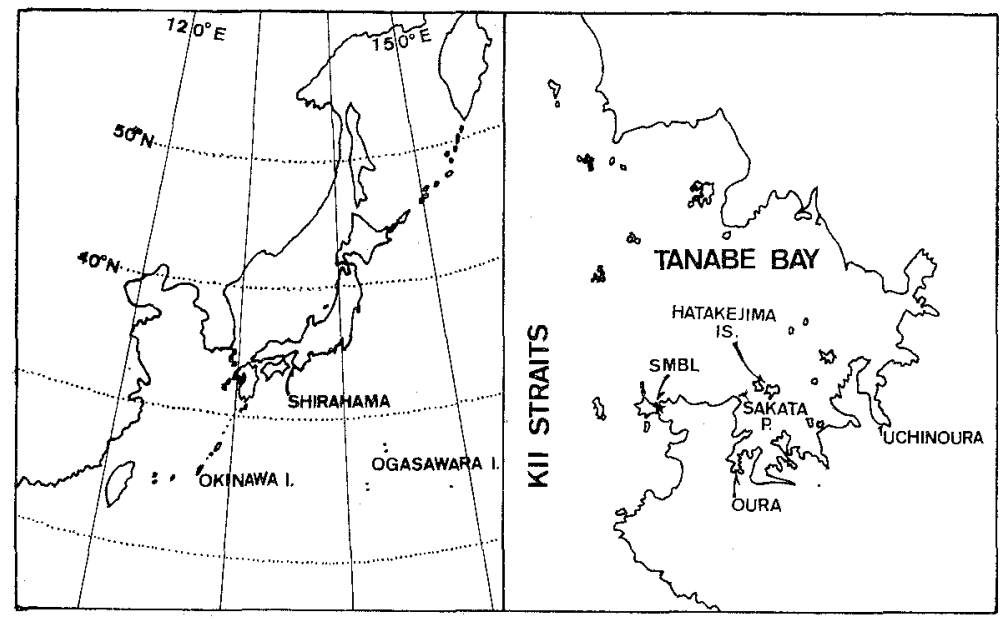

Fig. 1. The study area.

seasons from spring to fall and rather scarcely made during the cold season. My observations on the free swimming blennies, belonging to the tribe Nemophini, were also rather scarce and the comments on them were covered by the informations reported by Kuwamura (1980, 1981).

Most of collections were made using a dep net and the anethsetic quinaldine. Except as noted below, the method of counts and measurements follow Hubbs \& Lagler (1958). When the last anal soft ray divided at the base, it is counted as one ray. One short splintlike spine of the pelvic fin bound into investing membrane of the first soft ray is usually visible only after dissection or staining and excluded from the pelvic fin count. When the sharp distinction between spines and segmented soft rays of dorsal fin could not be established externally, the dorsal fin ray counts were expressed as total dorsal fin elements without distinction between them. All free tips of nasal, orbital and nuchal cirri were counted, except for nuchal cirri of Scartella, Girripertes and Exallias. On the nuchal cirri of these, when it is subdivided, it is counted as one. The numbers of pectoral and pelvic fin rays, nasal, orbital and nuchal cirri shown in tables or figures are expressed as totals for left and right sides. If specimens from other localities in Japan were available, they were briefly examined for comparison. The Shirahama and the compared specimens examined are deposited at the Department of Fisheries, Faculty of Agriculture, Kyoto University. In the sections of compared specimens, the range of standard length (expressed in $\mathrm{mm}$ ) of the specimens are shown in parenthesis following sex indication. The localities appeared in the paragraphs of Japanese localities are cited from the literature of the following authors, in addition to the results of present author. Aoyagi (1941, 1954, 1955), Araga \& Tanase (1966, 1968), Arai \& Abe (1970), Arai \& Ida (1975), Dotsu \& Nakamura (1976), Dotsu \& Tomiyama (1967), Honma (1977), Honma \& Sugihara (1963), Jordan et al. (1913), Kamohara (1950, 1957 a, b, 1958 a, b, 1964), Kamohara \& Yamakawa (1965, 1968), Katayama (1940, 1941), Katayama \& Fujioka (1958), Kato (1956), Kuwamura et al. (1983), Masuda et al. (1975, 1980), Matsubara (1955), Miura et al. (1973), Okada (1955), Schmidt (1930, 1931), Shiogaki \& Dotsu (1973), Shiogaki et al. (1971), Suzuki \& Kobayashi (1972), Tatara et al. (1965), Ueno (1971), Ui (1929), Yamakawa (1979), Yoshino \& Nishijima (1981), Yoshino et al. (1975), Zama \& Fujita (1977), and Zama \& Yasuda (1979).

\section{Annotated List of Species}

I. Blenniini

1. Pictiblennius yatabei (Jordan et Snyder, 1900)

Japanese name: Iso-ginpo (Fig. 27-A)

Common species. Twenty-four males $(30.0-63.2 \mathrm{~mm} \mathrm{SL}), 15$ females $(30.0-60.1 \mathrm{~mm} \mathrm{SL})$ and 
7 juveniles (17.2-28.2 $\mathrm{mm}$ SL) were examined. Dorsal fin rays XII, 14 to 17 ; anal fin rays II, 17 to 19 ; pectoral fin rays 12 to 15 ; pelvic fin rays 3 ; principal caudal rays 13 ; nasal cirri 1 to 4 ; orbital cirri 3 to 11 .

Compared specimens - Sado Island (Niigata Pref.): 1 male (52.1) and 2 females (43.7 and 43.8); Iki Island (Nagasaki Pref.): 1 male (32.2) and 3 females (45.9-60.2); Takahama (Fukui Pref.): 1 male (51.2) and 2 females (44.3 and 53.9); Maizuru (Kyoto Pref.): 3 males (71.8-78.2); Misaki (Kanagawa Pref.): 2 females (49.2 and 58.2).

Some meristic characters were shown in Tables 1,2 and Fig. 2. Except for the number of dorsal spines of a female from Takahama (XI), no significant difference

Table 1. Frequency distributions for some meristic characters in Pictiblennius yatabei

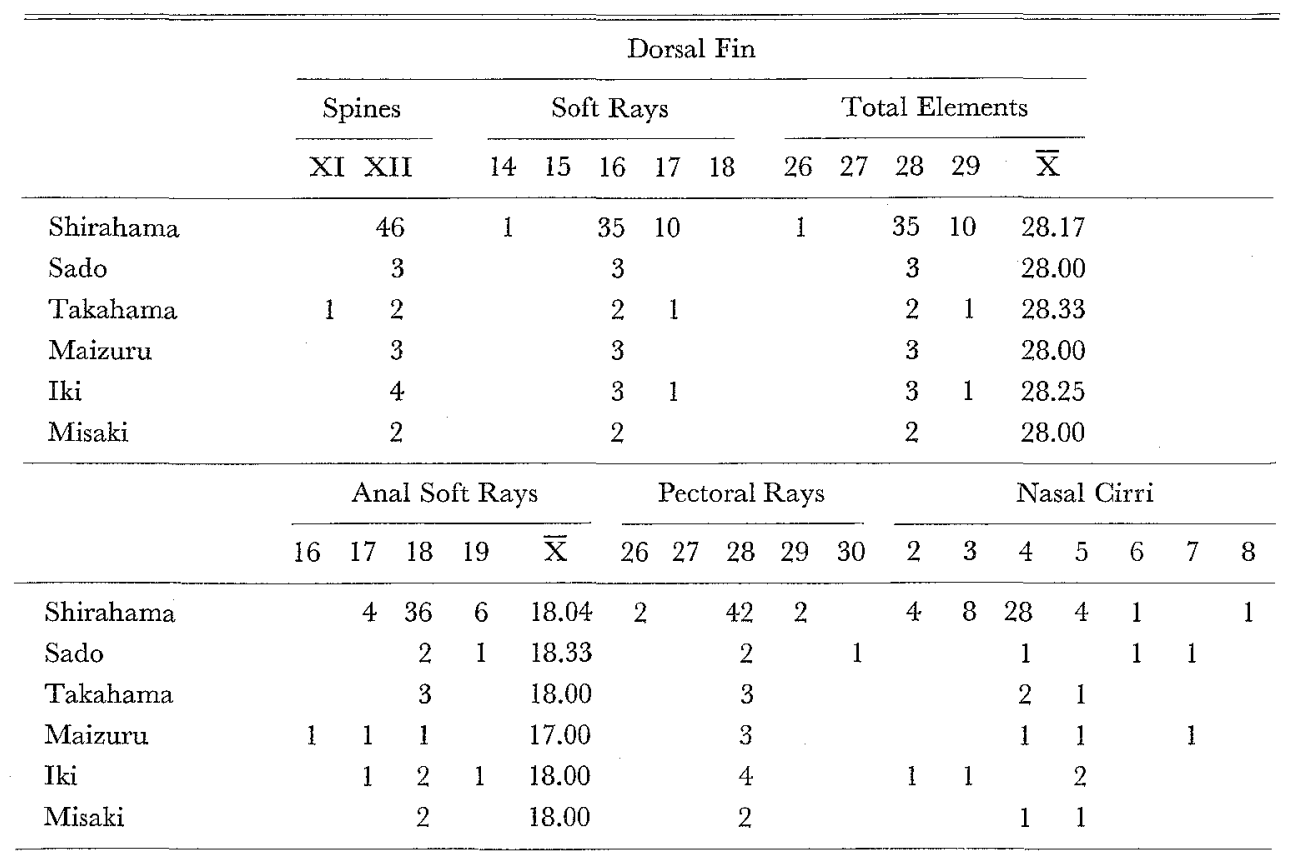

Table 2. The position of terminal anterior lateral line pore in Pictiblennius yatabei (given as dorsal fin spine under which the pore located).

\begin{tabular}{lcccccc}
\hline & & 7 & 8 & 9 & 10 & 11 \\
\hline Shirahama & (E) & 1 & 3 & 27 & 10 & \\
& (S) & & & & 3 & 2 \\
Sado & $(?)$ & & & 1 & 2 & \\
Takahama & (E) & & & 2 & 1 & \\
Maizuru & (S) & & & & & 3 \\
Iki & (E) & & & 2 & 2 & \\
Misaki & (S) & & & & 2 & \\
\hline
\end{tabular}

(E): exposed area;

(S): sheltered area;

(?) : unknown. 


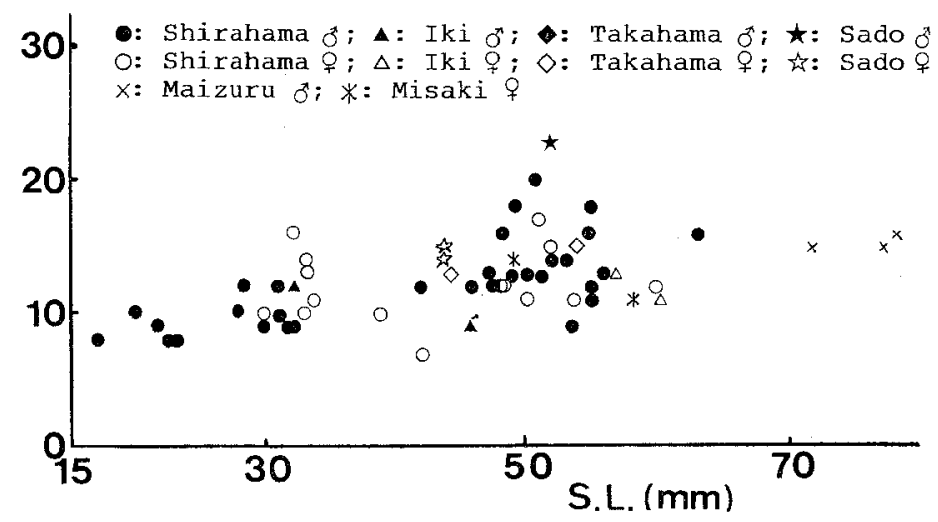

Fig. 2. The number of orbital cirri in Pictiblennius yatabei.

was noticed between Shirahama specimens and the compared specimens. A subtle difference was noticed in the position of the last pore of anterior lateral line, which is slightly swollen and followed bipore short tubes, between the specimens from sheltered area and those from exposed area. That of the former located at the point under the 10 th to 11 th dorsal spine, while that of the latter located at the point under the 8th to 10th (mostly 9th) dorsal spine. The collecting sites of Maizuru and Misaki were very sheltered areas, while those of Takahama and Iki Island were moderately exposed areas. That of Sado Island is unknown.

This species occurred from very sheltered to very exposed rocky reefs. Although they occurred widely in the study area, they were found rather sparsely in any sites observed. In the very exposed area, they seems to prefer the steep walls of rocky reefs and also were frequently found in tide pools. In the study area, they were found all the year round and spawnings were observed from late April to July.

Distribution: Japan and Korea.

Japanese localities: Yamagata Pref., Sado Island (Niigata Pref.), Toyama Pref., Takahama (Fukui Pref.), Maizuru (Kyoto Pref.), Oki Island (Shimane Pref.), Iki Island and Nomozaki (Nagasaki Pref.), Fukushima Pref., Chiba Pref., Misaki and Enoshima (Kanagawa Pref.), Shirahama and Wakanoura (Wakayama Pref.), Kochi Pref., Yamaguchi Pref., Amami Islands (Kagoshima Pref.).

2. Scartella cristata (Linnaeus, 1758)

Japanese name: Tategami-ginpo (Fig. 27-B)

Abundant species. Twenty males (30.1-62.7 mm SL) and 10 females (42.7-65.7 mm SL) were examined. Dorsal fin rays XII, 14 or 15 ; anal fin rays II, 14 to 17 ; pectoral fin rays 13 to 15 ; pelvic fin rays 3; principal caudal fin rays 13 ; nasal cirri 2 to 12 ; orbital cirri 2 to 12 ; nuchal cirri 6 to 12 .

Some meristic characters are shown in Table 3, Figs. 3 and 4. Bath (1970) compared specimens from the western Atlantic coast with those from the eastern Atlantic or Mediterranean and found the different tendencies in two morphological characters between above noted two geographical areas. One is that the specimens from the western Atlantic show a little higher rate of soft dorsal rays (78\% 15, 22\% 14) than the eastern Atlantic and Mediterranean material ( $72.5 \% 14,20 \% 15)$. 
Table 3. Frequency distributions for some meristic characters in Scartella cristata.

\begin{tabular}{|c|c|c|c|c|c|c|c|c|c|}
\hline \multicolumn{2}{|c|}{ D. Soft Rays } & \multicolumn{4}{|c|}{ A. Soft Rays } & \multicolumn{4}{|c|}{ Pectoral Rays } \\
\hline 14 & 15 & 14 & 15 & 16 & 17 & 27 & 28 & 29 & 30 \\
\hline 12 & 18 & 1 & 4 & 24 & 1 & 1 & 28 & & 1 \\
\hline
\end{tabular}

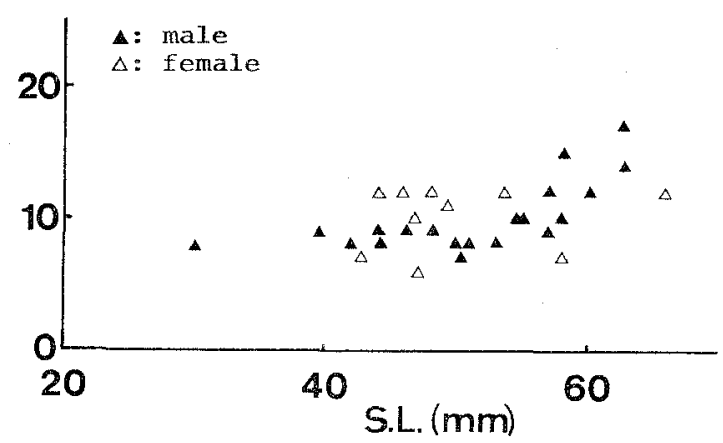

Fig. 3. The number of nasal cirri in Scartella cristata.

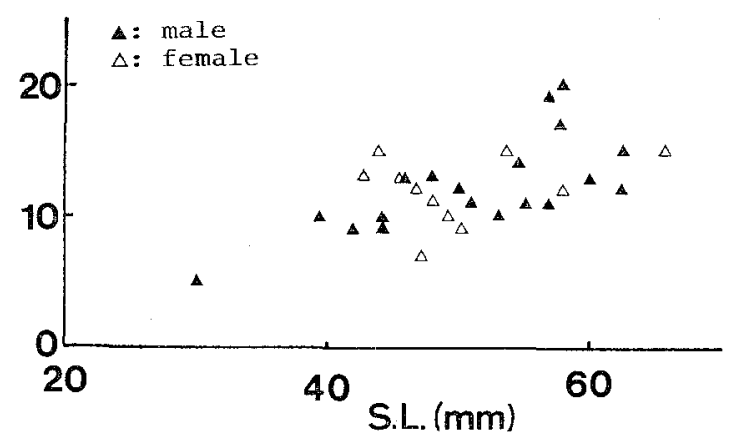

Fig. 4. The number of orbital cirri in Scartella cristata.

Another is that the former have strait to convex anterior head profil, while the latter have strait to concave anterior head profil, with a few exceptions. Shirahama specimens show intermediate rate of soft dorsal rays $(60 \% 15,40 \% 14)$ and have strait to convex anterior head profil. The number of nuchal cirri of Shirahama specimens $\overrightarrow{(\mathrm{X}}=8.1)$ is relatively few among the geographical populations reported by Bath (1970).

This species occurred only on very exposed rocky reefs, where they subdominated among blenniid species. In the study area, they were found all the year round and spawnings were observed to occur from April to December, with the peaks of its activity in spring and fall as well as in Florida (Smith, 1974).

Distribution: eastern Atlantic Ocean, Mediterranean Sea, Florida and Texas to Brazil in western Atlantic Ocean, and Japan.

Japanese localities: Shirahama (Wakayama Pref.), Kochi Pref. 
II. Omobranchini

3. Omobranchus elegans (Steindachner, 1876)

Japanese name: Nabeka (Fig. 27-G)

Common species. One male (48.9 $\mathrm{mm} \mathrm{SL}$ ) and 2 females (28.2 and $55.1 \mathrm{~mm} \mathrm{SL}$ ) were examined. Dorsal fin rays XII, 20 to 22 ; anal fin rays II, 22; pectoral fin rays 13; pelvic fin rays 2; principal caudal fin rays 13 .

Compared specimens -Maizuru (Kyoto Pref.): 2 females (50.9 and 59.2); Misaki (Kanagawa Pref.): 1 male (59.4).

Dorsal fin formula of 3 compared specimens is the same XII, 21. No significant difference was noticed between Shirahama specimens and the compared specimens.

This species occurred from very sheltered to moderately exposed rocky reefs. They were rather rare on moderately exposed reefs. In the study area, they were found all the year round. The courtship behavior of a male, showing the circling up into the water column near the nest hole when a female approached and the subsequent spawning were observed once on 22 June, 1973.

Distribution: Japan, southern Korea, and Shantung Province, China.

Japanese localities: west to the Erimo Point and Hakodate (Hokkaido Pref.), Sado Island (Niigata Pref.), Toyama Bay (Toyama Pref.), Uchiura Bay and Takahama (Fukui Pref.), Maizuru (Kyoto Pref.), Oki Island (Shimane Pref.), Iki Island, Tsushima Island, Goto Islands and Nomozaki (Nagasaki Pref.), Chiba Pref., Yokohama, Misaki and Hayama (Kanagawa Pref.), Izu Peninsula (Shizuoka Pref.), Shirahama and Wakanoura (Wakayama Pref.), Seto Inland Sea, Shimonoseki (Yamaguchi Pref.), Tomioka and Akune (Kumamoto Pref.), Kikaijima Island (Kagoshima Pref.).

4. Omobranchus fasciolatoceps (Richardson, 1846)

Japanese name: Tosaka-ginpo (Fig. 27-D)

Rare species. One male ( $56.1 \mathrm{~mm} \mathrm{SL})$ and 2 females ( 50.0 and $53.5 \mathrm{~mm} \mathrm{SL}$ ) were examined. Dorsal fin rays XII, 19 or 20; anal fin rays II, 21 or 22; pectoral fin rays 13 or 14; principal caudal rays 13 ; total procurrent rays 5 to 7 .

Except for the number of procurrent rays which is 5 to 7 instead of 11 to 13 and anal fin ray counts of a female which is II, 21 instead of II, 22 to 24 , no significant difference was noticed between Shirahama specimens and the fishes described by Springer and Gomon (1975). Katayama and Ikeda (1973) reported an anal-fin count of II, 21 for a specimen from Yamaguchi Prefecture, Japan.

This species were found together with Omobranchus punctatus in or among empty shells of bivalves, Spondylus barbatus barbatus and Chlamys (Mimachlamys) nobilis which were wasted and piled up on the shore of Oura, which is located at the very sheltered innermost part of Tanabe Bay (Fig. 1). Observation at Oura was made only once on 14 June, 1979. The observation was conducted during low tide of spring tide and the shells in or among which the fishes hide were far out of water. A male collected has well developed lateral extensions (tabs) on the anterior 7 anal fin rays which was found in the case of presumably mature males of Omobranchus (Springer \& Gomon, 1975) and whose function was thought to be associated with the reproduction 
in some blenniid species (Smith, 1974). According to these facts and the geographical distribution of this species, the reproduction may occur in the study area although no egg mass was found in this study. Judging from their geographical distribution, they may also survive over the cold season in the study area.

Distribution: coast of mainland China from Macao and Hong Kong north to Japan.

Japanese localities: Toyama Bay (Toyama Pref.), Tokyo Pref., Lake Hamana (Shizuoka Pref.), Toyohashi (Aichi Pref.), Shirahama (Wakayama Pref.), Kochi Pref.

5. Omobranchus loxozonus (Jordan et Starks, 1906)

Japanese name: Kumo-ginpo (Fig. 27-E)

Common species. Ten males (26.2-65.0 mm SL), 12 females $(31.0-55.0 \mathrm{~mm} \mathrm{SL})$ and 4 youngs (20.0-26.2 $\mathrm{mm} \mathrm{SL)} \mathrm{were} \mathrm{examined.} \mathrm{Dorsal} \mathrm{fin} \mathrm{rays} \mathrm{XII} \mathrm{or} \mathrm{XIII,} 19$ to 21 ; anal fin rays II, 20 to 23 ; pectoral fin rays 12 or 13 ; pelvic fin rays 2 ; principal caudal fin rays 13 ; lateral line tubes $0-2$.

Compared specimens -Okinawajima Island (Okinawa Pref.): 6 males (31.0-49.9) and 7 females (31.9-41.3); Ishigakijima Island (Okinawa Pref.): 7 males (29.9-61.2) and 5 females (23.9$40.9)$.

Some meristic characters are shown in Table 4. Springer \& Gomon (1975) reported that variation in meristic characters was noted only in the Okinawa population of $O$. loxozonus, which tended to have higher averages for most characters. There is no discrepancy between my results and those of Springer \& Gomon (1975). When my results and the data in Table 12 of Springer \& Gomon (1975) were considered together, however, the number of total dorsal fin elements \& segmented anal fin rays seem to increase gradually in populations from north to south localities.

This species occurred from sheltered to moderately exposed rocky reefs. They were frequently found in small and shallow tide pools, rather highly-placed in the intertidal zone. Four egg masses, each of which were guarded by a male, were found in empty shells of Serpulorbis imbricatus on the rocky flat in the intertidal zone of Hatakejima Island on 30 June, 1973. At the observation, which was conducted

Table 4. Frequency distributions for some meristic characters in Omobranchus loxozonus.

\begin{tabular}{|c|c|c|c|c|c|c|c|c|c|c|c|c|c|c|c|}
\hline & \multicolumn{15}{|c|}{ Dorsal Fin } \\
\hline & \multicolumn{5}{|c|}{ Spines } & \multicolumn{4}{|c|}{ Soft Rays } & \multicolumn{6}{|c|}{ Total Elements } \\
\hline & XII & & III & $\mathrm{XIV}$ & & 19 & 20 & 21 & 22 & 31 & 32 & 33 & 34 & 35 & $\overline{\mathrm{X}}$ \\
\hline Shirahama & 2 & & 24 & & & 7 & 17 & 2 & & 1 & 7 & 16 & 2 & & 32.73 \\
\hline Okinawajima & 1 & & 10 & 2 & & & 7 & 6 & & & & 7 & 5 & 1 & 33.54 \\
\hline \multirow[t]{3}{*}{ Ishigalkijima } & & & 11 & 1 & & 1 & 2 & 6 & 3 & & & 3 & 6 & 3 & 34.00 \\
\hline & \multicolumn{8}{|c|}{ Anal Soft Rays } & \multicolumn{4}{|c|}{ Pectoral Rays } & & & \\
\hline & 20 & 21 & 22 & 23 & 24 & 25 & $\overline{\mathrm{X}}$ & & 25 & 26 & 27 & & & & \\
\hline Shirahama. & 1 & 3 & 17 & 5 & & & 22.00 & & 1 & 25 & & & & & \\
\hline Okinawajima & & & 4 & 8 & & 1 & 22.85 & & & 12 & 1 & & & & \\
\hline Ishigakijima & & & 2 & 4 & 5 & 1 & 23.42 & & 1 & 11 & & & & & \\
\hline
\end{tabular}


during low tide of spring tide, each empty shell in which egg mass was found was far out of water. In the study area, they were found all the year round.

Distribution: southern Japan.

Japanese localities: Kominato (Chiba Pref.), Goto Islands and Nomozaki (Nagasaki Pref.), Shirahama (Wakayama Pref.), Seto Inland Sea, Toyohama (Kagawa Pref.), Kochi Pref., Nobeoka (Miyazaki Pref.), Yakushima Island, Tanegashima Island and Amami Islands (Kagoshima Pref.), Okinawa Islands, Miyako Island and Ishigakijima Island (Okinawa Pref.).

6. Omobranchus punctatus (Valenciennes, 1836)

Japanese name: Idaten-ginpo (Fig. 27-F)

Abundant species. Seven males $(71.3-95.3 \mathrm{~mm} \mathrm{SL})$ and 14 females $(38.9-85.8 \mathrm{~mm} \mathrm{SL})$ were examined. Total dorsal fin elements 32 to 35 (32 in 1 ind., 33 in 12 inds., 34 in 7 inds., 35 in 1 ind.); anal fin rays II, 22 to 25 (22 in 1 ind., 23 in 9 inds., 24 in 6 inds., 25 in 5 inds.); pectoral fin rays 12 to 14 (mostly 13); pelvic fin rays 2; principal caudal fin rays 12 or 13 (12 in 1 ind.).

Springer \& Gomon (1975) reported that population variation was noted in most meristic characters of $O$. punctatus. The modal numbers of total dorsal fin elements and of soft anal fin rays in Shirahama specimens are 33 and 23, respectively, whereas those in Japanese specimens (3 from Nagasaki Pref., 1 from Miyazaki Pref., 2 from Wakayama Pref., 1 from Hiroshima Pref., 1 from Tokyo and 1 from Seto Inland Sea) presented in Table 13 of Springer \& Gomon (1975) are 34 and 24, respectively. Except for the above, no significant difference was noticed between Shirahama specimens and the fish described by Springer and Gomon (1975).

This species were abundantly found in or among empty shells of bivalves, Spondylus barbatus barbatus and Chlamys (Mimachlamys) nobilis on the shore of Oura. They were also found commonly among cobbles in the shore of the Sakata Point which located at the inner part of Tanabe Bay. For the purpose of the display in aquarium, they are collected by hook and line in the shore of Uchinoura, located at the innermost part of the Bay, where they are abundantly found among cobbles (Araga, pers. comm.). They could not be found in moderately to vrey exposed rocky reefs. Four egg masses, each of which was guarded by a male, were found inside shells on 14 June, 1979 in the course of observation at Oura. Judging from the size of collected specimens and their geographical distribution, they may survive over the cold season in the study area.

Distribution: from the Persian Gulf to Japan and eastern Australia.

Japanese localities: Toyama Bay (Toyama Pref.), Chiba Pref., Tokyo Pref., Oki Island (Shimane Pref.), Seto Inland Sea, Hiroshima Pref., Yamaguchi Pref., Wakanoura and Shirahama (Wakayama Pref.), Kochi Pref., Okinawa Islands and Miyako Islands (Okinawa Pref.).

\section{Nemophini}

7. Aspidontus dussumieri (Valenciennes, 1836)

Japanese name: Kurosuji-ginpo

Very rare species. No specimens examined. This species occurred around the moderately exposed rocky reefs. Kuwamura (1981) reported that the occurrence 
of this species almost restricted seasonaly to summer and fall.

Distribution: widely distributed throughout most of Indo-Pacific.

Japanese localities: Shirahama and Wakanoura (Wakayama Pref.), Seto Inland Sea, Okinawa Islands (Okinawa Pref.).

8. Aspidontus taeniatus taeniatus Quoy and Gaimard, 1834

Japanese name: Nise-kurosuji-ginpo

Rare species. Although no specimen has been examined, the fishes observed in this study may be safely assigned to the subspecies, $A$. $t$. taeniatus, based on their geographical distribution. Another nominal subspecies, A. t. tractus Fowler, is essentially restricted to the Red Sea and the Indian Ocean (Smith-Vaniz, 1976). The distinguishing character between the subspecies, the presence or absence of a black bar on the fleshy pectoral fin base, coincide with the color pattern of each local population of Labroides dimidiatus, to which these subspecies mimic (Smith-Vaniz, 1976).

This species occurred around the moderately to very exposed rocky reefs. Kuwamura (1981) reported about the some aspects of ecology of this species, mainly on their mimicry to Labroides dimidiatus in the study area. He reported that the minimum individual was $46 \mathrm{~mm}$ TL (measured after collected) and the maximum was about $100 \mathrm{~mm}$ TL, observed in the study area during the years from 1972 to 1980 . The occurrence of this species mostly restricted to summer and fall and they seldom survive over the cold season in the study area (Kuwamura, 1981). Araga and Tanase (1968) reported that 3 individuals (83-100 $\mathrm{mm}$ TL) stranded on the beach, killing by the cold in January, 1968 when the water temperature went down sharply from $15.3^{\circ} \mathrm{C}$ to $10.1^{\circ} \mathrm{G}$.

Distribution: widely distributed in the western and central Pacific Oceans.

Japanese localities: Aburatsubo and Misaki (Kanagawa Pref.), Izu Peninsula (Shizuoka Pref.), Shirahama (Wakayama Pref.), Amami Islands (Kagoshima Pref.), Okinawa Islands (Okinawa Pref.).

9. Meiacanthus (Meiacanthus) atrodorsalis atrodorsalis (Günther, 1877)

Japanese name: Ogon-niji-ginpo

Very rare species. No specimens examined. The fishes observed in this study may be safely assigned to the subspecies, $M$. (M.) a. atrodorsalis, based on their geographical distribution. Another nominal subspecies, $M .(M)$. a. ovalauensis (Günther) is endemic to the Fiji Islands (Smith-Vaniz, 1976).

This species occurred around the moderately exposed rocky reefs. The occurrence of this species restricted seasonaly to summer and fall.

Distribution: widely distributed in the central and western Pacific Oceans.

Japanese localities: Shirahama (Wakayama Pref.), Okinawa Islands and Ishigakijima Island (Okinawa Pref.).

10. Meiacanthus (Meiacanthus)kamoharai Tomiyama, 1956

Japanese name: Kamohara-ginpo

Rather rare species. No specimens examined. This species occurred around 
the moderately to very exposed rocky reefs. Kuwamura (1980) reported that the observed individuals of this species were ranging from about 40 to $100 \mathrm{~mm}$ TL and that they were found year round in the years from 1973 to 1975, but only juveniles appearing from July to January in 1976-1977 in the study area. Araga \& Tanase (1968) reported that 2 individuals (57 and $62 \mathrm{~mm}$ TL) stranded on the beach, killing by the cold in January, 1968 in the study area. An egg mass which was guarded by a male (ca. $100 \mathrm{~mm}$ TL) was found inside wall of empty shell of a bivalvia on 11 October, 1975.

Distribution: endemic to Japan.

Japanese localities: Shirahama (Wakayama Pref.), Kochi Pref., Tanegashima Island and Amami Islands (Kagoshima Pref.), Okinawa Islands (Okinawa Pref.), Miyakejima Island and Ogasawara Islands (Tokyo Pref.).

\title{
11. Petroscirtes (Dasson) breviceps (Valenciennes, 1836)
}

Japanese name: Niji-ginpo (Fig. 27-G)

\begin{abstract}
Abundant species. One male $(30.9 \mathrm{~mm} \mathrm{SL}), 4$ females $(33.1-57.0 \mathrm{~mm} \mathrm{SL}$ ) and 7 youngs (16.1$29.5 \mathrm{~mm}$ SL) were examined. Total dorsal fin elements 29 to 32 ; anal fin rays II, 18 to 21 ; pectoral fin rays 13 to 15 ; pelvic fin rays 3 ; principal caudal rays 11 ; nasal cirrus simple or absent; orbital cirrus simple or absent; postorbital cirrus simple or absent; symphyseal mandibular cirrus simple or absent (absent in youngs).

Compared specimens -Iki Island (Nagasaki Pref.): 2 females (67.5 and 81.9); Okinawajima Island (Okinawa Pref.): 1 male (79.2).
\end{abstract}

Some meristic characters are shown in Table 5. No significant difference was observed between Shirahama specimens and the compaired specimens. The ventral stripe in specimens examined is variously developed as in fishes from the Gulf of Tailand and populations in the South China Sea reported by Smith-Vaniz (1976).

Table 5. Frequency distributions for some meristic characters in Petrocsirtes (Dasson) breviceps.

\begin{tabular}{|c|c|c|c|c|c|c|c|c|c|c|c|c|c|c|}
\hline & \multicolumn{5}{|c|}{ Total Dorsal Elements } & \multicolumn{5}{|c|}{ Anal Soft Rays } & \multicolumn{4}{|c|}{ Pectoral Rays } \\
\hline & 29 & 30 & 31 & 32 & $\overline{\mathrm{X}}$ & 18 & 19 & 20 & 21 & $\overline{\mathrm{X}}$ & 27 & 28 & 29 & 30 \\
\hline Shirahama & 1 & 3 & 8 & 1 & 30.69 & 2 & 4 & 6 & 1 & 19.46 & 1 & 11 & & 1 \\
\hline Iki & & 1 & 1. & & 30.50 & & 2 & & & 19.00 & & 2 & & \\
\hline Okinawajima & & 1 & & & 30.00 & & 1 & & & 19.00 & & & 1 & \\
\hline
\end{tabular}

This species occurred from sheltered to very exposed rocky reefs. They were rather rare around the very exposed area. They were abundantly seen in the surgassum belt of Hatakejima Island (Kuwamura, pers. comm.). Youngs (ca. 20-30 $\mathrm{mm}$ TL) were sometimes found abundantly among the branches of drifting surgassum near shore from early September to late October. An egg mass guarded by a male was once observed inside wall of empty bivalvia which attached underside of a scrapped boat in late July of 1973. They were found all the year round in the study area. 
Distribution: widely distributed in the Indian and West Pacific Oceans, but unknown from the Red Sea, Persian Gulf or eastern Australia.

Japanese localities: west to the Erimo Point (Hokkaido Pref.), Sado Island (Niigata Pref.), Toyama Bay (Toyama Pref.), Oki Island (Shimane Pref.), Iki Island, Tsushima Island, Goto Islands, Hirado Island and Nomozaki (Nagasaki Pref.), Chiba Pref., Misaki (Kanagawa Pref.), Izu Peninsula (Shizuoka Pref.), Shirahama (Wakayama Pref.), Seto Inland Sea, Kochi Pref., Amami Islands (Kagoshima Pref.), Okinawa Islands (Okinawa Pref.), Ogasawara Islands (Tokyo Pref.).

12. Plagiotremus (Musgravius) laudandus laudandus (Whitley, 1961)

Japanese name: Inase-ginpo

Very rare species. No specimen examined. The fishes observed in this study may be safely assigned to the subspecies, $P$. (M.) l. laudandus, based on their geographical distribution. Another nominal subspecies, $P$. (M.) $l$. flavus, is endemic to Fiji Islands. Smith-Vaniz (1976) stated that only coloration will distinguish flavus from the allopatric nominal subspecies, and their respective distributions are almost certainly influenced by the distribution of the two subspecies of Meiacanthus atrodorsalis to which they mimic.

This species occurred around the moderately exposed rocky reefs. Kuwamura (1981) reported that only 4 individuals of about 50-60 $\mathrm{mm}$ TL were observed during the years from 1972 to 1980 and that the occurrence of them mostly restricted to summer and fall in the study area.

Distribution: widely distributed in the central and western Pacific Oceans, with notable exception of the Fiji Islands.

Japanese localities: Shirahama (Wakayama Pref.), Okinawa Islands and Ishigakijima Island (Okinawa Pref.).

13. Plagiotremus (Runula) rhinorhynchus (Blecker, 1852)

Japanese name: Minami-ginpo

Common species. No specimens examined. This species occurred around the moderately to very exposed rocky reefs. Kuwamura (1981) reported that the observed individuals of this species were ranged from about $30-100 \mathrm{~mm}$ TL (individuals with adult color pattern ranging from about $70-100 \mathrm{~mm}$ TL) and that, in the case of mild winter, fairely many individuals survive over the cold season in the study area.

Distribution: widely distributed throughout the Indo-Pacific.

Japanese localities: Moroiso (Kanagawa Pref.), Izu peninsula (Shizuoka Pref.), Shirahama and Susami (Wakayama Pref.), Kochi Pref., Yakushima Island (Kagoshima Pref.), Okinawa Islands and Ishigakijima Island (Okinawa Pref.), Ogasawara Islands (Tokyo Pref.).

14. Plagiotremus (Runula) tapeinosoma (Bleeker, 1857)

Japanese name: Ten-kurosuji-ginpo (Fig. 27-H)

Common species. One male (54.2 mm SL) was examined. Total dorsal elements 45 ; anal rays II, 31; pectoral rays 12; pelvic rays 2 ; principal caudal rays 11 ; total procurrent rays 14 .

Compared specimens -Okinawa Islands (Okinawa Pref.): 2 males (49.8 and 76.1) and 1 female (68.1); Ishigakijima Island (Okinawa Pref.): 1 male (68.1); Ogasawara Islands (Tokyo Pref.): 1 female (60.1). 
Except for anal fin soft ray count of a male from the Okinawa Islands, which is 32 instead of 31 , the fin ray counts of the compared specimens are the same as those of Shirahama specimens. A subtle difference was noticed in color pattern between a Shirahama specimen and the compared specimens. The Shirahama specimen has a trace of dark stripe ventrally which is faint and not so developed as that in fish from the Gulf of Aqaba reported by Smith-Vaniz (1976), while the compared specimens have no pigmentation ventrally. The number of total dorsal fin elements and soft anal fin rays of examined specimens are intermediate between those of specimens from Indian Ocean and those from the other localities presented by Smith-Vaniz (1976).

This species occurred around the moderately to very exposed rocky reefs. Kuwamura (1981) reported that the observed individuals of this species were ranged from $50-100 \mathrm{~mm}$ TL and that, in the case of mild winter, fairly many individuals survive over the cold season in the study area.

Distribution: widely distributed throughout the Indo-Pacific.

Japanese localities: Izu Peninsula (Shizuoka Pref.), Shirahama, Susami and Karekinada (Wakayama Pref.), Kochi Pref., Kikaijima Island (Kagoshima Pref.), Okinawa Islands and Ishigakijima Island (Okinawa Pref.), Miyakejima Island and Ogasawara Islands (Tokyo Pref.).

IV. Salariini

15. Cirripectes castaneus (Valenciennes, 1836)

Japanese name: Tategami-kaeruuo

Very rare species. One female $(52.2 \mathrm{~mm} \mathrm{SL})$ was examined. Dorsal fin rays XII, 14; anal fin rays II, 15; pectoral fin rays 15; pelvic fin rays 4; principal caudal fin rays 13; nasal cirri 8 (left) or 7 (right); orbital cirri 9 (left) or 6 (right); nuchal cirri 33 . This fish was described in detail by Fukao (1984).

Only a single individual was observed and collected by Dr. Kuwamura on 18 Oct. 1975. This fish hid under a shrub coral, Acropora sp. on moderately exposed rocky reef.

Distribution: Isle-de-France (Mauritius), Sula Island, Ambon, Japan.

Japanese localities: Shirahama (Wakayama Pref.).

16. Cirripectes kuwamurai Fukao, 1984

Japanese name: Suji-tategami-kaeruuo

Very rare species. One female (55.9 mm SL) was examined. Dorsal fin rays XII, 16; anal fin rays II, 17; pectoral fin rays 15; pelvic fin rays 4; principal caudal fin rays 13; nasal cirri 4 (left) or 3 (right); orbital cirri 8 (left) or 5 (right); nuchal cirri 30 . This fish was described in detail by Fukao (1984).

Only a single individual was observed and collected by Dr. Kuwamura on 4 May, 1974. This fish hid under a shrub coral, Acropora sp. on moderately exposed rocky reef.

Distribution: hitherto known only from the study area. 
17. Cimipectes polyzona (Bleeker, 1868)

Japanese name: Mino-kaeruuo

Common species. Eleven males (20.2-54.2 mm SL) and 9 females $(19.8-57.1 \mathrm{~mm} \mathrm{SL})$ were examined. Dorsal fin rays XII, 14; anal fin rays II, 15; pectoral fin rays 15; pelvic fin rays 3 or 4 (mostly 4); nasal cirri 4 to 15; orbital cirri 6 to 27; nuchal cirri 34 to 54 . This species was described in detail together with the fish from the Okinawa Islands and from the Ogasawara Islands by Fukao (1984).

This species occurred on moderately to very exposed rocky reefs. In moderately exposed reefs, they were found among interstices of or under the shrub corals, Acropora spp. In very exposed reefs, they were mostly found in or near the empty shells of Balanus tintinnabrum volcano. As already reported (Fukao, 1984), they may not survive over the cold season and the reproduction may not occur in the study area.

Distribution: South Africa, western Indian Ocean, Polynesia, Micronesia, East Indies, Japan.

Japanese localities: Shirahama (Wakayama Pref.), Kochi Pref., Yakushima Island, Tanegashima Island and Amami Islands (Kagoshima Pref.), Okinawa Islands, Miyako Islands and Ishigakijima Island (Okinawa Pref.), Ogasawara Islands (Tokyo Pref.).

18. Entomacrodus caudofasciatus (Regan, 1909)

Japanese name: Aomon-ginpo (Fig. 27-I)

Common species. Twelve males (25.8-57.3 mm SL) and 2 females (40.1 and $47.1 \mathrm{~mm} \mathrm{SL)}$ were examined. Dorsal fin rays XIII or XIV, 14 or 15; anal fin rays II, 16 or 17; pectoral fin rays 14; pelvic fin rays 4; principal caudal fin rays 13 ; nasal cirri 4 to 10 (mostly simple and rarely bifulcate); orbital cirri 4 to 8 ; nuchal cirrus simple.

Compared specimens -Okinawa Islands (Okinawa Pref.): 2 females (26.7 and 39.9); Ogasawara Islands (Tokyo Pref.): 7 males (26.2-55.8) and 3 females $(27.0-37.8)$.

Some meristic characters were shown in Table 6, Figs. 5 and 6. Springer (1967) described five different color pattern types, which are allopatric each other,

Table 6. Frequency distributions for some meristic characters in Entomacrodus caudofasciatus.

\begin{tabular}{|c|c|c|c|c|c|c|c|c|c|c|c|}
\hline & \multicolumn{11}{|c|}{ Dorsal Fin } \\
\hline & \multicolumn{4}{|c|}{ Spines } & \multicolumn{3}{|c|}{ Soft Rays } & \multicolumn{4}{|c|}{ Total Elements } \\
\hline & XII & & & XIV & 14 & 15 & 16 & 37 & 38 & 39 & $\overline{\mathrm{X}}$ \\
\hline Shirahama & & & 3 & 1 & 1 & 13 & & 1. & 12 & 1 & 38.00 \\
\hline Ogasawara & 1 & & 9 & & 2 & 7 & 1 & 2 & 8 & & 37.80 \\
\hline \multirow[t]{3}{*}{ Okinawa } & & & 2 & & & 2 & & & 2 & & 38.00 \\
\hline & \multicolumn{4}{|c|}{ Anal Soft Rays } & \multicolumn{3}{|c|}{$\mathbf{P}_{1}$. Rays } & \multicolumn{4}{|c|}{ PTALLP } \\
\hline & 15 & 16 & 17 & $\overline{\mathrm{X}}$ & 28 & 29 & 30 & 9 & 10 & 11 & 12 \\
\hline Shirahama & & 12 & 2 & 16.14 & 13 & & 1 & & 4 & 10 & \\
\hline Ogasawara & 1 & 9 & & 15.90 & 10 & & & 1 & 3 & 4 & 1 \\
\hline Okinawa & & 2 & & 16.00 & 2 & & & & & 2 & \\
\hline
\end{tabular}

PTALLP: the position of terminal anterior lateral line pore (given as dorsal fin elements under which the pore located). 


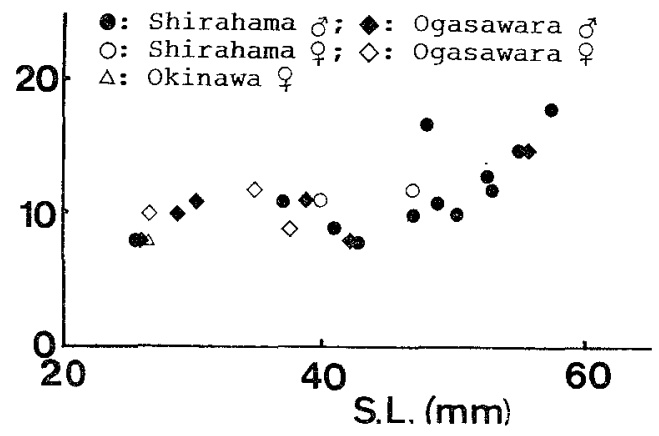

Fig. 5. The number of nasal cirri in Entomacrodus caudofasciatus.

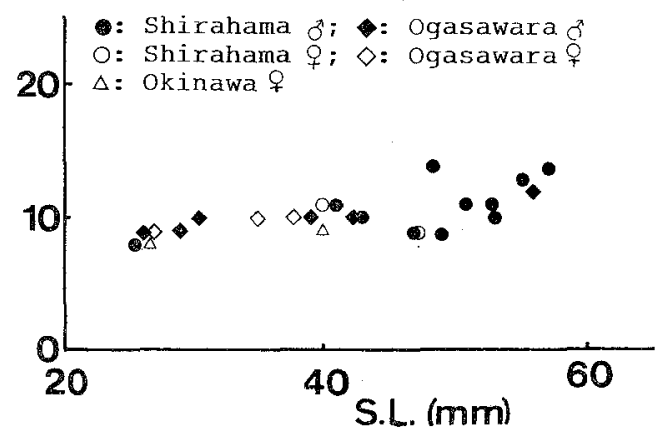

Fig. 6. The number of orbital cirri in Entomacrodus caudofasciatus.

within a species, E. caudofasciatus. Specimens from Shirahama, Ogasawara and Okinawa agree well with the number 4 type which occurred in specimens from Poulo C'ecir de Mer, McKean, Swains, Tutuila, Tau and Tongatapu Islands (Springer, 1967) and from Taiwan (Springer, 1972).

This species occurred only on very exposed rocky reefs. Spawnings were observed to occur from June to October in the study area. They were found all the year round.

Distribution: mid eastern Indian Ocean, South China Sea, Taiwan, Japan, Zulu Sea, and the tropical western Pacific from the Palaus to Raroia.

Japanese localities: Shirahama (Wakayama Pref.), Danjo Islands (Nagasaki Pref.), Okinawa Islands (Okinawa Pref.), Ogasawara Islands (Tokyo Pref.).

19. Entomacrodus stellifer stellifer (Jordan et Snyder, 1902)

Japanese name: Hoshi-ginpo (Fig. 27-J)

Abundant species. Eighteen males (28.9-108.9 mm SL) and 16 females $(49.3-81.2 \mathrm{~mm} \mathrm{SL})$ were examined. Dorsal fin rays XIII, 14 to 17; anal fin rays II, 16 to 19; pectoral fin rays 13 or 14; pelvic fin rays 3 or 4; principal caudal fin rays 12 or 13 (12 in 1 ind.); nasal cirri 1 to 18 ; orbital cirri 1 to 10 (mostly simple); nuchal cirri 1 to 5 (mostly simple).

Compared specimens - Iki Island (Nagasaki Pref.): 3 males (56.8-80.2) and 11 females (52.195.2); Nomozaki (Nagasaki Pref.): 1 male (79.9) and 1 female (61.9); Takahama (Fukui Pref.): 2 males (73.8 and 103.2). 
Some meristic characters are shown in Table 7 and Fig. 7. No significant difference was noticed between Shirahama specimens and the compared specimens. Springer (1976) stated, "Though few speicmens are available, it appears that Japanese specimens have lower average counts than do specimens from the other localities (Okinawa and Saipan)." Present data are not inconsistent with the above noted Springer's notice, but the ranges of fin ray counts in specimens from Japan (excluding Okinawa) were extended (soft dorsal rays, 14 to 17 instead of 15 to 16 ; soft anal rays 15 to 19 instead of 17 to 18 ). In addition to this, the range extention of the number of orbital cirri ( 1 to 10 instead of 1 to 3 ) was observed in the present study to the data presented by Springer (1967). The percentage of specimens with simple

Table 7. Frequency distributions for some meristic characters in Entomacrodus stellifer stellifer.

\begin{tabular}{|c|c|c|c|c|c|c|c|c|c|c|c|c|}
\hline & \multicolumn{5}{|c|}{ D. Soft Rays } & & \multicolumn{6}{|c|}{ A. Soft Rays } \\
\hline & 14 & 15 & 16 & 17 & $\overline{\mathrm{X}}$ & & 15 & 16 & 17 & 18 & 19 & $\overline{\bar{X}}$ \\
\hline Shirahama & 1 & 5 & 27 & 1 & 15.82 & & & 1 & 11 & 19 & 3 & 17.71 \\
\hline Nomozaki & & & 2 & & 16.00 & & & & & 2 & & 18.00 \\
\hline Iki & & 4 & 8 & 2 & 15.86 & & 1 & & 5 & 8 & & 17.73 \\
\hline \multirow[t]{3}{*}{ Takahama } & & & 2 & & 16.00 & & & & & 2 & & 18.00 \\
\hline & \multicolumn{3}{|c|}{$\mathrm{P}_{1}$. Rays } & & \multicolumn{3}{|c|}{$P_{2}$. Rays } & \multicolumn{5}{|c|}{ PTALLP } \\
\hline & 27 & 28 & 29 & & 6 & 7 & 8 & 11 & 12 & 13 & 14 & 15 \\
\hline Shirahama & 1 & 33 & & & 3 & 8 & 23 & & 16 & 13 & 4 & 1 \\
\hline Nomozaki & & 1 & 1 & & & & 2 & & & 1 & 1 & \\
\hline $\mathrm{Iki}$ & & 14 & & & 4 & 1 & 9 & 1 & 7 & 6 & & \\
\hline Takahama & & 2 & & & & & 2 & & 1 & 1 & & \\
\hline
\end{tabular}

PTALLP: position of terminal anterior lateral line pore (given as dorsal fin elements under which the pore located).

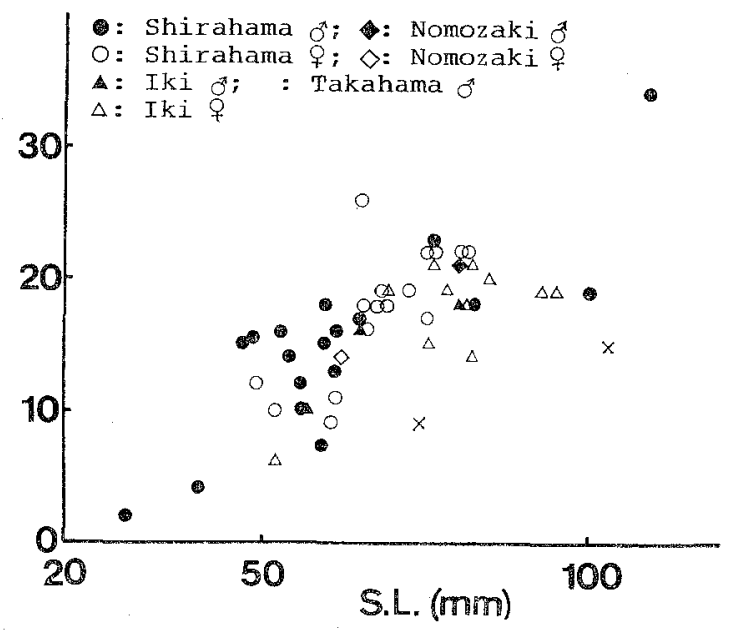

Fig. 7. The number of nasal cirri in Entomacrodus stellifer stellifer. 
orbital cirrus in the present study is 61.5 instead of over 90 in Springer (1967). The plural cirri show bifulcate, trifulcate, or a main cirrus with branches like $E$. striatus as a whole.

This species occurred from moderately to very exposed rocky reefs. They dominated in the intertidal zone of very exposed rocky reefs, but seldom occur in tide pools. Spawnings were observed to occur from middle May to middle September, with the peak of its activity in July and August. They were seen all the year round.

Distribution: Saipan and Japan.

Japanese localities: Kominato (Chiba Pref.), Suruga Bay (Shizuoka Pref.), Wakanoura and Shirahama (Wakayama Pref.), Seto Inland Sea, Kochi Pref., Okinawajima Island (Okinawa Pref.), Amakusa (Kumamoto Pref.), Goto Islands, Danjo Islands, Iki Island, Tsushima Island and Nomozaki (Nagasaki Pref.), Egumi (Shimane Pref.), Takahama and Uchiura Bay (Fukui Pref.), Toyama Pref., Sado Island (Niigata Pref.).

20. Entomacrodus striatus (Quoy et Gaimard, 1836)

Japanese name: Suji-ginpo (Fig. 27-K)

Rather rare species. Six males $(32.2-54.9 \mathrm{~mm} \mathrm{SL})$ and 3 females (31.7-49.8 mm SL) were examined. Dorsal fin rays XIII, 15 or 16 ; anal fin rays II, 16 or 17 ; pectoral fin rays 14; pelvic fin rays 4 ; principal caudal fin rays 13 ; nasal cirri 3 to 6 , palmate as a whole; orbital cirri 3 to 10 ; nuchal cirrus simple.

Compared specimens —Okinawajima Island (Okinawa Pref.): 1 female (45.9); Miyakojima Island (Okinawa Pref.): 1 male (56.3); Ogasawara Islands (Tokyo Pref.): 8 males (38.7-69.9) and 7 females $(33.8-47.9)$.

Some meristic characters are shown in Table 8, Figs. 8 and 9. Springer (1967) stated about the color variations of the species as follows, "In Marshall Islands specimens, the pale striping on the underside of the head may be very conspicuous. Pale spots and dashes may extend onto the upper lip, snout, and sides of the head. In specimens from many diverse localities, the only distinct markings are the large dark spots along the midlateral length of the body. Some specimens from the South China Sea have strong indications of the diffuse, dark, bandlike extensions dorsally from the concentrated areas of body spots, and some specimens exhibit three diffuse vertical bands on the upper lip."

Table 8. Frequency distributions for some meristic characters in Entomacrodus striatus.

\begin{tabular}{|c|c|c|c|c|c|c|c|c|c|c|c|c|c|}
\hline & \multicolumn{3}{|c|}{ D. Soft Rays } & \multicolumn{3}{|c|}{ A. Soft Rays } & \multicolumn{7}{|c|}{ PTALLP } \\
\hline & 15 & 16 & $\overline{\mathrm{X}}$ & 16 & 17 & $\overline{\mathrm{X}}$ & 6 & 7 & 8 & 9 & 10 & 11 & 12 \\
\hline Shirahama & 6 & 3 & 15.33 & 1 & 8 & 16.89 & & & & 3 & 1 & 4 & 1 \\
\hline Okinawajima & 1 & & 15.00 & 1 & & 16.00 & & & & 1 & & & \\
\hline Miyakojima & 1 & & 15.00 & 1 & & 16.00 & & & 1 & & & & \\
\hline Ogasawara & 6 & 9 & 15.60 & 6 & 9 & 16.60 & 1 & & 3 & 8 & 3 & & \\
\hline
\end{tabular}

PTALLP: position of terminal anterior lateral line pore (given as dorsal fin elements under which the pore located). 


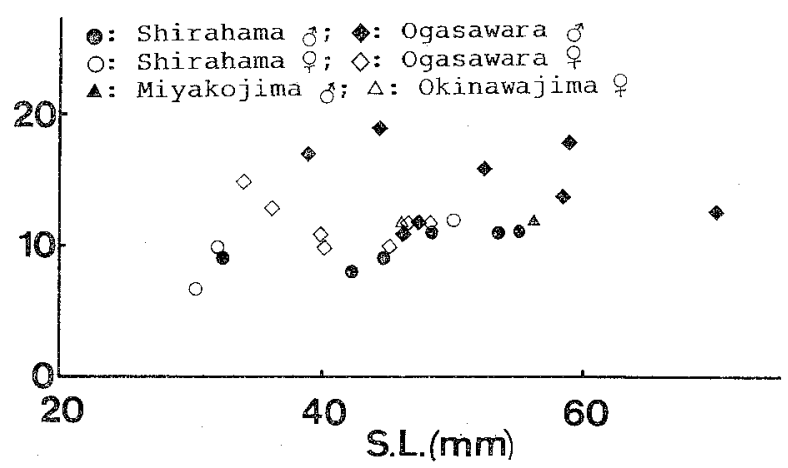

Fig. 8. The number of nasal cirri in Entomacrodus striatus.

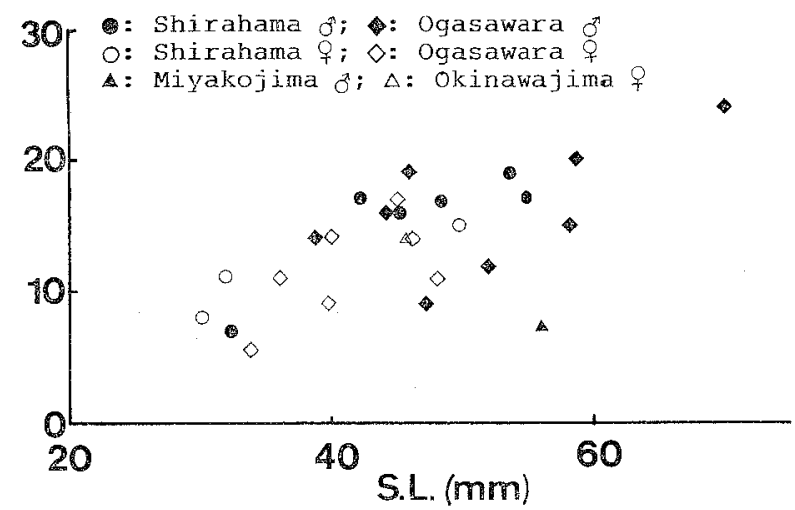

Fig. 9. The number of orbital cirri in Entomacrodus striatus.

The pale striping on the underside of the head were variable from almost unrecognizable to very conspicuous in both Shirahama specimens and the compared specimens. When alive or in freshly preserved specimens, however, it was always very conspicuous and constituted of $\mathrm{V}$-shaped stripes and spots arranged in $\mathrm{V}$-shape row, sometimes extending onto the upper lip, snout, and sides of the head. This color variation, therefore, may possibly be the result of the condition of preservation. The indications of the diffuse, dark, bandlike extensions were recognizable in all specimens from Shirahama and the compared specimens.

Springer (1967) also stated about the variation on a fusion of the spots in the humeral area. Dark humeral blotches or slender spots appeared variable on both Shirahama specimens and the compared specimens as well as on specimens from Pacific Ocean and South China Sea reported by Springer (1967). In addition to the above, Springer (1967) reported about the variation in the number of lateral cirri branches on the main orbital cirrus and in the relative length of the main orbital cirrus, which ocucr in certain populations. Most of the larger (over $40 \mathrm{~mm}$ SL) specimens examined in the present study have lateral branches on the main orbital cirrus. The relative length of the main orbital cirrus are shown in Fig. 10. 


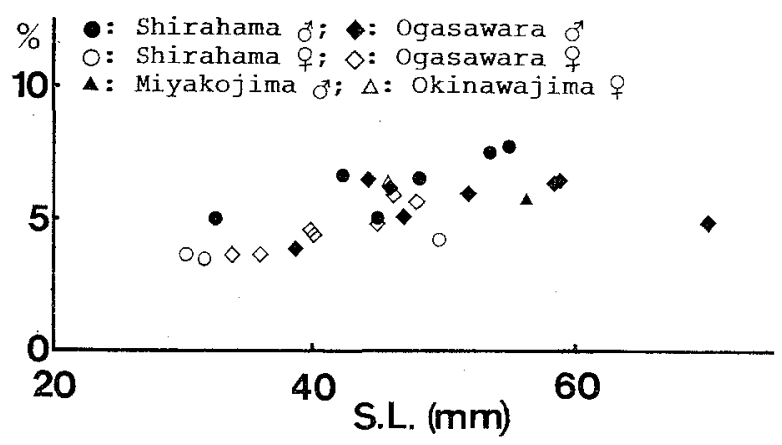

Fig. 10. The relative length of the main orbital cirrus in Entomacrodus striatus. Expressed as percent of standard length.

This species occurred only on very exposed rocky reefs. Spawnings were observed to occur in September and October. They could servive ovre the cold season, at least, in the case of mild winter in the study area.

Distribution: from the Indian Ocean to Raroia, Tuamotus, in the Pacific Ocean. South China Sea and Japan.

Japanese localities: Shirahama (Wakayama Pref.), Kochi Pref., Danjo Islands (Nagasaki Pref.), Tokara Islands and Amami Islands (Kagoshima Pref.), Okinawajima Island and Miyakojima Island (Okinawa Pref.), Ogasawara Islands (Tokyo Pref.).

21. Entomacrodus thalassinus (Jordan et Seale, 1906)

$\left\{\begin{array}{l}\text { E. t. thalassinus (Jordan et Seale, 1906) } \\ \text { Japanese name: Goten-kaeruuo (Fig. 28-L) } \\ \text { E. t. longicirrus Springer, } 1967\end{array}\right.$

New Japanese name: Tsunonaga-goten-kaeruuo (Fig. 28-M)

Rather rare species. Fourteen males (19.1-38.3 mm SL) and 5 females (24.2-31.2 mm SL) were examined. Dorsal fin rays XII or XIII, 13 to 15 ; anal fin rays II, 15 or 16; pectoral fin rays 13 to 15 ; pelvic fin rays 4 ; principal caudal rays 13 ; nasal cirri 1 to 6 ; orbital cirri 2 to 7 ; nuchal cirrus simple.

Compared specimens -Ogasawara Islands (Tokyo Pref.): 2 males (24.3 and 25.7) and 4 females $(21.9-24.5)$.

Some meristic characters are shown in Table 9, Figs. 11 and 12. The relative length of the longest or the main orbital cirrus is shown in Fig. 13. Springer (1967) established the subspecies, $E$. $t$. longicirrus based mainly on the relative length of orbital cirrus, which is longer than that of the other subspecies, E. t. thalassinus. The ranges of relative length of orbital cirrus after Springer (1967, Fig. 11) are shown at the right side in Fig. 13.

In the relative length of orbital cirri, 16 specimens from Shirahama are out of the range of $E$. $t$. thalassinus and nearly fit the range of $E$. $t$. longicirrus. Two males from Shirahama and 2 males from Ogasawara are within the range of the former subspecies and far out of that of the latter. One female from Shirahama and 4 females from Ogasawara are within the overlapping range of both subspecies. 
In addition to the above noted character, Springer (1967) noted, "There are minor differences in color pattern, which are manifested in $E$. $t$. longicirrus having more melanic pigment." This character appeared not always to provide a distinct separation between these two forms in this study.

Springer (1967) described two types of orbital cirri configuration in the section of $E$. thalassinus without comments on the difference between two subspecies. In this study, all the above noted specimens within the range of $E$. $t$. thalassinus in the relative length of orbital cirri have almost the same type of orbital cirri configuration, subequal and arising from a common base, although some variations exist (Fig. 14$\mathrm{A}, \mathrm{B}, \mathrm{C})$. Inversely, the orbital cirri of others are another type, main or longest

Table 9. Frequency distributions for some meristic characters in Entomacrodus thalassinus.

\begin{tabular}{|c|c|c|c|c|c|c|c|c|c|c|c|c|}
\hline & \multicolumn{12}{|c|}{ Dorsal Fin } \\
\hline & \multicolumn{3}{|c|}{ Spines } & \multicolumn{3}{|c|}{ Soft Rays } & \multicolumn{6}{|c|}{ Total Elements } \\
\hline & $\mathrm{XI}$ & $\mathrm{X}$ & & 13 & 14 & 15 & & & 27 & 28 & & $\overrightarrow{\mathrm{X}}$ \\
\hline \multirow{2}{*}{ Shirahama } & 2 & & & 1 & 13 & 2 & & 3 & 11 & 2 & & 5.94 \\
\hline & & & 3 & & 3 & & & & 3 & & & 7.00 \\
\hline \multirow[t]{3}{*}{ Ogasawara } & & & 5 & & 4 & 1 & & & 4 & 1 & & 7.20 \\
\hline & \multicolumn{3}{|c|}{ A. Soft Rays } & \multicolumn{3}{|c|}{$P_{1}$. Rays } & \multicolumn{6}{|c|}{ PTALLP } \\
\hline & 15 & 16 & $\overline{\mathrm{X}}$ & 27 & 28 & 29 & 7 & 8 & 9 & 10 & 11 & 12 \\
\hline \multirow{2}{*}{ Shirahama } & 3 & 13 & 15.81 & 3 & 13 & & & 5 & 5 & 5 & & 1 \\
\hline & & 3 & 16.00 & & 2 & 1 & & 1 & 1 & 1 & & \\
\hline Ogasawara & 1 & 4 & 15.80 & & 4 & 1 & 1 & 1 & 4 & & & \\
\hline
\end{tabular}

PTALLP: position of terminal anterior lateral line pore (given as dorsal fin elements under which the pore located).

$(l)$ : longicirrus; $(t)$ : thalassinus.

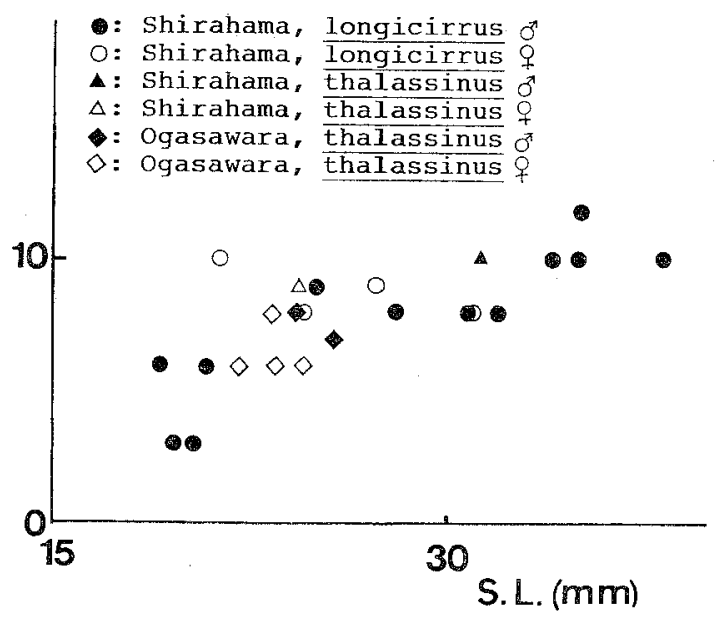

Fig. 11. The number of nasal cirri in Entomacrodus thalassinus. 


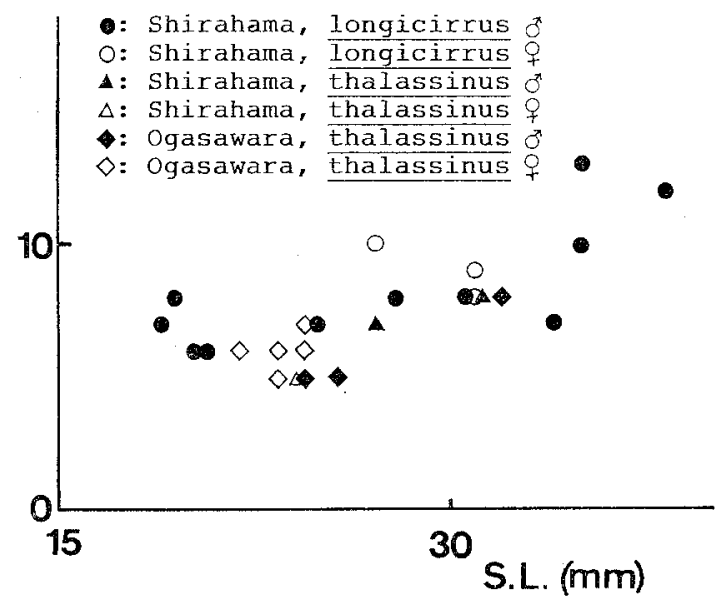

Fig. 12. The number of orbital cirri in Entomacrodus thalassinus.

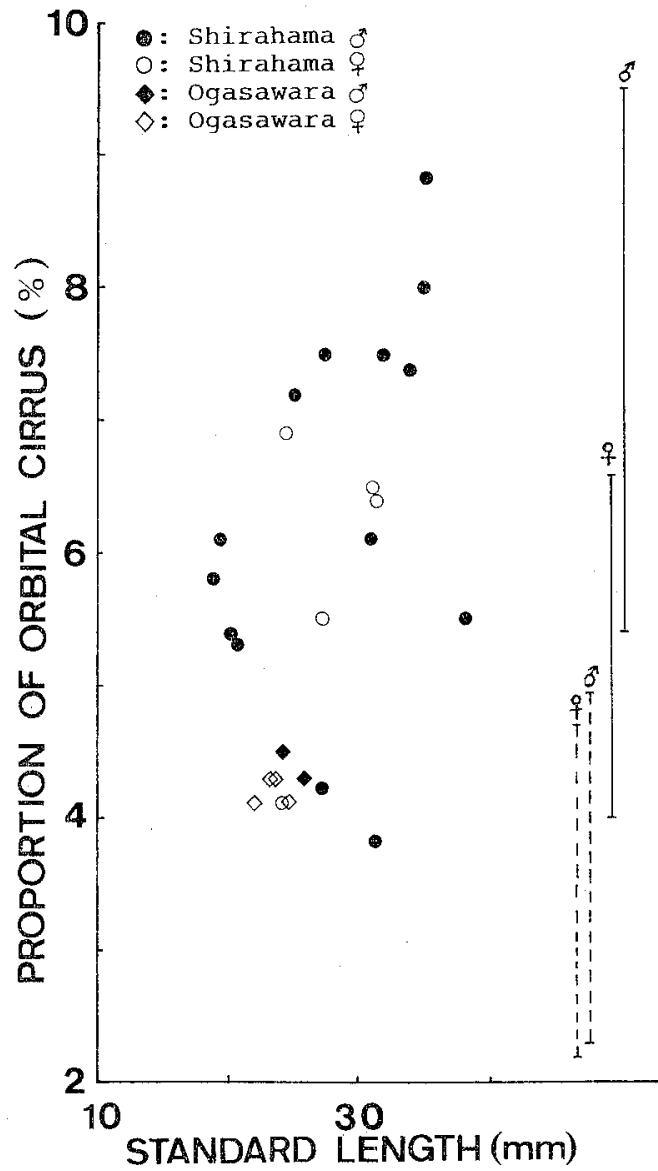

Fig. 13. The relative length of the longest or the main orbital cirrus in Entomacrodus thalassinus. Expressed as the percent of standard length. The vertical solid and brocken lines at the right show the ranges of relative length of orbital cirrus of longicirrus and thalassinus after Springer (1967, Fig. 11), respectively. 


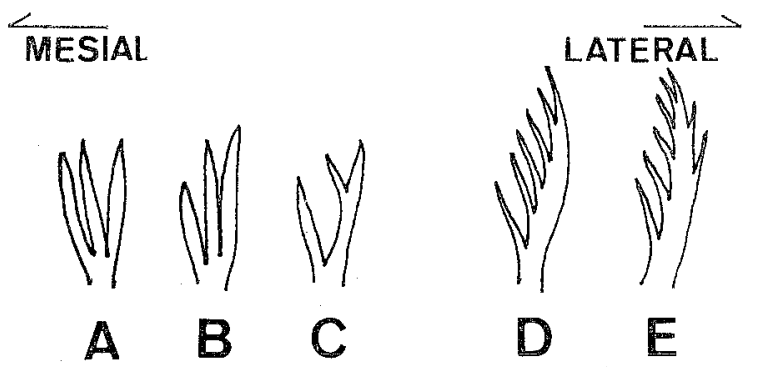

Fig. 14. The typical orbital cirri configuration of Entomacrodus thalassinus.

cirrus with short branches mesially, rarely 1 or 2 branches laterally (Fig. 14-D, E). This character seems to be an effective one in separation of these two forms in the present study, though it is unknown whether this is true or not in populations from other localities. If this is true, fish from Ogasawara belong to the subspecies, $E$. $t$. thalassinus and both subspecies occur sympatric in Shirahama. Unfortunately, I could not obtain the specimens from Okinawa. However, Springer (1967) synonymized Salarias lacunicola Fowler with $E$. $t$. thalassinus, because the noncrenulated ventral margin of upper lip, presence of vomerine teeth, color pattern, short supraorbital cirrus and low gill-raker and fin ray counts are sufficient to synonymize: $S$. lacunicola was described based on the fish from Ryuku Islands (Okinawa Islands) by Fowler (1946). Although I feel that the absence of E. $t$. longicirrus in Okinawa Islands still remains in question, Shirahama is located at the extreme periphery in the geographical distribution of both forms. In the present study, I follow the standpoint that the two forms might emigrate to Shirahama after the isolation was once established between these two forms (subspecies).

Observation at fields colud not distinguish between two forms. This species occurred only on the very exposed rocky reefs. The courtship behavior that a male showed quick several reciprocating action, in and out his nest hole when a female approached, once observed on 12 Aug. 1975. Moreover, several larger males (including 1 of $E$. $t$. thalassinus form) have well developed dermal pad of anal spine. Although egg masses could not be found in this study, the reproduction may occur in the study area. They could survive over the cold season, at least, in the case of mild winter in the study area.

Distribution: E. t. thalassinus - from the Seychelles, Indian Ocean, and in Pacific from Japan to Raroia. E. t. longicirrus - South China Sea and its extension, the Gulf of Thailand and Japan.

Japanese localities: E. t. thalassinus - Shirahama (Wakayama Pref.), Okinawa Islands (Okinawa Pref.), Ogasawara Islands (Tokyo Pref.). E. t. longicirres - Shirahama (Wakayama Pref.).

22. Exallias brevis (Kner, 1868)

Japanese name: Sedakaminpo (Fig. 28-N)

Very rare species. One male $(48.8 \mathrm{~mm} \mathrm{SL})$ and 1 female $(34.1 \mathrm{~mm} \mathrm{SL})$ were examined. Dorsal fin rays XII, 12 or 13; anal fin rays II, 14; pectoral fin rays 15; pelvic fin rays 4; principal caudal fin rays 13; nasal cirri 6 to 8 ; orbital cirri 5 to 12 ; nuchal cirri 32 and 35 . 
Compared specimens -Takarajima Island (Kagoshima Pref.): 1 female (91.0); Okinawa Islands (Okinawa Pref.): 1 male (53.6) and 4 females (49.8-75.9); Ogasawara Islands (Tokyo Pref.): 6 males $(40.7-62.0)$ and 6 females (44.4-96.3).

Some meristic characters are shown in Table 10, Figs. 15 and 16. No signifcant difference was noticed between Shirahama specimens and the compared specimens, or the fishes described by Strasbrug and Schultz (1953), Lee (1979), and by Smith-Vaniz \& Springer (1979).

Only two individuals were observed in interstices of Acropora spp. on moderately exposed rocky reefs. Kuwamura (1976) also reported that this species (ca. $60 \mathrm{~mm}$ TL) was observed in interstices of Acropora sp. in the study area. A male observed and collected on 18 Oct. 1975 attained $48.8 \mathrm{~mm}$ in SL (63.0 $\mathrm{mm}$ TL), but the dermal pads of anal spine was only weakly developed. The reproduction may not occur in the study area. They may not be able to survive ovre the cold season.

Table 10. Frequency distributions for some meristic characters in Exallias brevis.

\begin{tabular}{|c|c|c|c|c|c|c|c|c|c|c|c|c|c|c|c|}
\hline & \multicolumn{5}{|c|}{ D. Soft Rays } & \multicolumn{4}{|c|}{ A. Soft Rays } & \multicolumn{3}{|c|}{$\mathbf{P}_{1}$. Rays } & & & \\
\hline & 12 & 13 & & $\overline{\mathrm{X}}$ & & & 3 & 14 & $\overline{\mathrm{X}}$ & & 29 & 30 & & & \\
\hline Shirahama & 1 & 1 & 1 & 12.50 & & & & 2 & 14.00 & & & 2 & & & \\
\hline Takarajima & & 1 & 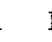 & 13.00 & & & & 1 & 14.00 & & & 1 & & & \\
\hline Okinawa & 2 & 3 & 3 & 12.60 & & & & 5 & 14.00 & & & 5 & & & \\
\hline \multirow[t]{3}{*}{ Ogasawara } & 1 & 11 & & 12.92 & & & 1 & 11 & 13.92 & & 1 & 11 & & & \\
\hline & \multicolumn{15}{|c|}{ Nuchal Cirri } \\
\hline & 27 & 28 & 29 & 30 & 31 & 32 & 33 & 34 & $35 \quad 36$ & 37 & 38 & 39 & 40 & 41 & 42 \\
\hline Shirahama & & & & & & 1 & & & 1 & & & & & & \\
\hline Takarajima & & & & & & 1 & & & & & & & & & \\
\hline Okinawa & & & & & & 1 & & 1 & 2 & & & & & & 1 \\
\hline Ogasawara & 1 & 1 & & 1 & & 1 & 3 & & 2 & & & & 2 & & \\
\hline
\end{tabular}

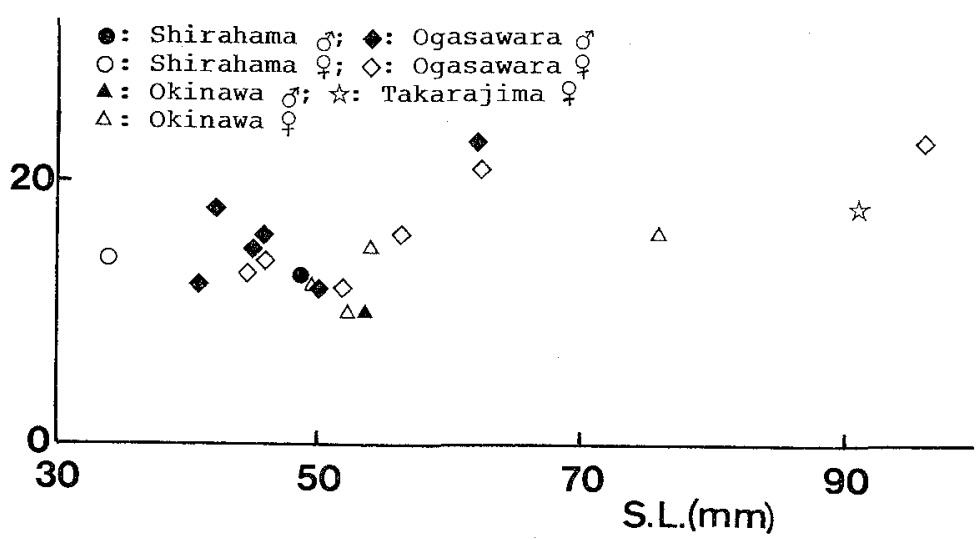

Fig. 15. The number of nasal cirri in Exallias brevis. 


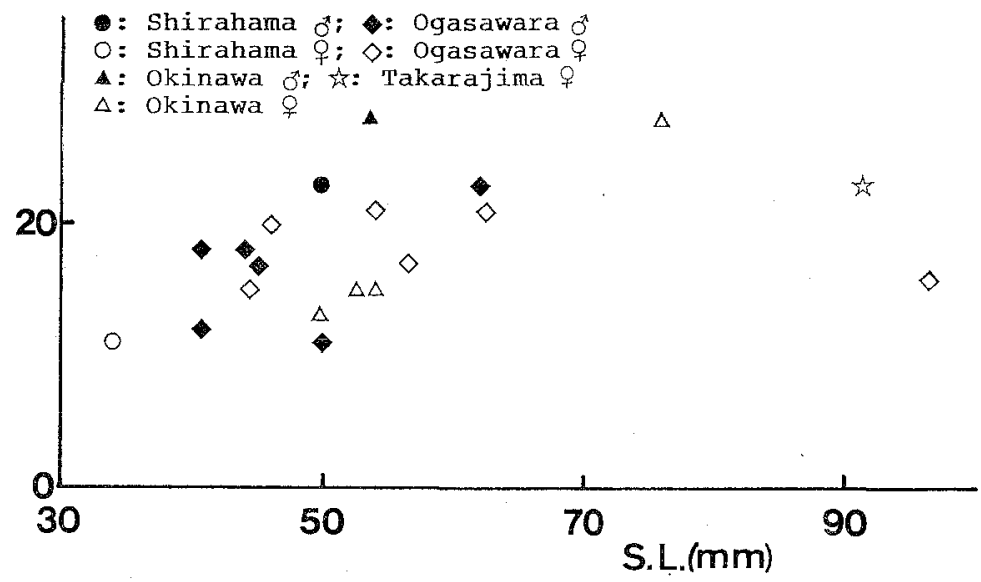

Fig. 16. The number of orbital cirri in Exallias brevis.

Distribution: Red Sea, Indian Ocean, central and western Pacific Oceans.

Japanese localities: Shirahama (Wakayama Pref.), Okinawa Islands (Okinawa Pref.), Ogasawara Islands (Tokyo Pref.).

23. Istiblennius bilitonensis (Bleeker, 1858)

Japanese name: Hohoguro-ginpo (Fig. 28-O)

Very rare species. One female (36.2 $\mathrm{mm} \mathrm{SL)} \mathrm{was} \mathrm{examined.} \mathrm{Dorsal} \mathrm{fin} \mathrm{rays} \mathrm{XIII,} \mathrm{20;} \mathrm{anal}$ fin rays II, 20; pectoral fin rays 14; pelvic fin rays 3 ; principal caudal fin rays 13; nasal cirri 3, palmate as a whole; orbital cirrus simple; no crest on head.

Compared specimens -Yoronto Island (Kagoshima Pref.): 1 female (67.9); Okinawajima Island (Okinawa Pref.): 5 males (37.0-64.2) and 5 females (24.8-69.9); Ishigakijima Island (Okinawa Pref.): 4 males (42.3-66.1) and 5 females (46.6-70.3); Iriomotejima Island (Okinawa Pref.): 2 females (39.7 and 52.0).

Some meristic characters are shown in Table 11 and Fig. 17. Chapman (1951) noted that no crest on head in female. In the larger females (over $40 \mathrm{~mm} \mathrm{SL}$ ) of the compared specimens, however, the rudimentary crest (fleshy ridge) was observed on the head.

During the course of this study, only a single individual of small female was

Table 11. Frequency distributions for some meristic characters in Istiblennius bilitonensis.

\begin{tabular}{|c|c|c|c|c|c|c|c|c|c|c|c|c|}
\hline & \multicolumn{4}{|c|}{ D. Soft Rays } & \multicolumn{3}{|c|}{ A. Soft Rays } & \multicolumn{2}{|c|}{$P_{1}$. Rays } & \multicolumn{3}{|c|}{ PTALLP } \\
\hline & 19 & 20 & 21 & $\overline{\mathrm{x}}$ & 20 & 21 & $\bar{x}$ & 28 & 29 & 8 & 9 & 10 \\
\hline Shirahama & & 1 & & 20.00 & 1 & & 20.00 & 1 & & & 1 & \\
\hline Yoronto & & 1 & & 20.00 & 1 & & 20.00 & I & & & 1 & \\
\hline Okinawajima & 2 & 7 & 1 & 19.90 & 6 & 4 & 20.40 & 9 & 1 & 4 & 3 & 3 \\
\hline Ishigakijima & 2 & 5 & 2 & 20.00 & 4 & 5 & 20.56 & 9 & & 2 & 7 & \\
\hline Iriomotejima & & 2 & & 20.00 & 2 & & 20.00 & 2 & & & 1 & 1 \\
\hline
\end{tabular}

PTALLP: position of terminal anterior lateral line pore (given as dorsal fin elements under which the pore located). 


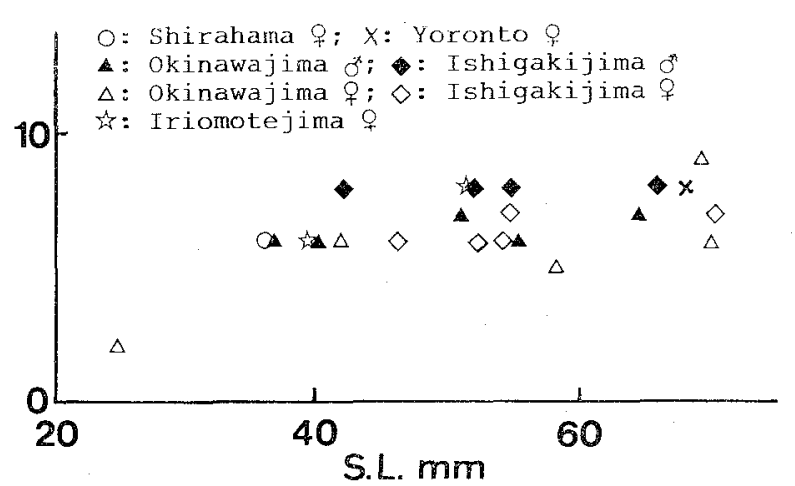

Fig. 17. The number of nasal cirri in Istiblennius bilitonensis.

once observed and collected. It was found in the intertidal of moderately exposed rocky reef on 16 November, 1973.

Distribution: western Pacific Ocean.

Japanese localities: Shirahama (Wakayama Pref.), Yakushima Island, Tanegashima Island and Kikaijima Island (Kagoshima Pref.), Okinawa Islands, Miyakojima Island and Yaeyama Islands (Okinawa Pref.).

24. Istiblennius edentulus (Bloch, 1801)

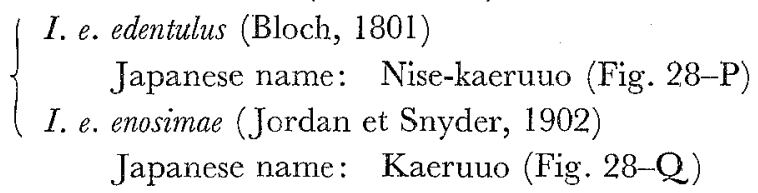

Abundant species. Twenty-two males (33.2-113.7 mm SL) and 22 females (33.3-112.8 mm SL) were examined. Dorsal fin rays XII to XIV, 19 to 22; anal fin rays II, 20 to 23; pectoral fin rays 13 to 15 ; pelvic fin rays 2 or 3 ; nasal cirri 1 to 11 ; orbital cirri 1 to 5 (mostly simple); nuchal cirri simple.

Compared specimens --Iki Island. (Nagasaki Pref.): 1 male (64.2); Nomozaki (Nagasaki Pref.): 2 females (97.2 and 106.7); Takarajima Island (Kagoshima Pref.): 1 male (46.2); Yoronto Island (Kagoshima Pref.): 1 female (70.2); Okinawajima Island (Okinawa Pref.): 15 males (24.2-96.0) and 11 females (19.7-98.5); Ishigakijima Island (Okinawa Pref.): 13 males (21.0-58.7) and 8 females (36.8-78.1): Iriomotejima. Island (Okinawa Pref.): 1 male (56.3) and 2 females (47.2 and 80.1).

Some meristic characters are shown in Table 12, Figs. 18 and 19. Chapman (1951) noted that the forms of this species ( $=$ I. edentulus) which inhabit southern Japan, Hawaii, and the Marquesas Islands are probably sub-specifically distinct. The so-called Japanese form, however, has been treated as full species, I. enosimae (Jordan et Snyder) (e.g. Masuda et al., 1975, 1980; Ichthyological Society of Japan, 1981). The distinct characters of enosimae were represented in the presence of crest and the color pattern of the adult female. In enosimae, both sexes have crest and same coloration (Masuda et al., 1980). The females of edentulus have no crest and in the Pacific Ocean, they differ from the male strigingly in coloration. In male, the body is generally payler, the dorsal fins, the base of the caudal and the 
posterior half of the body are covered thickly with prominent small, black spots that are persistent in preservation (Chapman, 1951).

The both edentulus and enosimae type colorations were occurred in females of Shirahama specimens and of the compared specimens. Fig. 20 shows the degree of development of crest in females examined, giving the 4 ranks of valuation (N: no

Table 12. Frequency distributions for some meristic characters in Istiblennius edentuluts.

\begin{tabular}{|c|c|c|c|c|c|c|c|c|c|c|c|c|c|c|c|}
\hline & & \multicolumn{14}{|c|}{ Dorsal Fin } \\
\hline & & \multicolumn{4}{|c|}{ Spines } & \multicolumn{4}{|c|}{ Soft Rays } & \multicolumn{6}{|c|}{ Total Elements } \\
\hline & & XII & XII & II & XIV & 19 & 20 & 21 & 22 & 31 & 32 & 33 & $34 \quad 35$ & 36 & $\bar{X}$ \\
\hline \multirow[t]{3}{*}{ Shirahama } & $(\tilde{0})$ & & 21 & 1 & 1 & 1 & 14 & 7 & & & 1 & 13 & 8 & & 33.32 \\
\hline & $(\mathrm{n} q)$ & & 16 & 6 & 1 & & 5 & 11 & 1 & & & 4 & 121 & & 33.82 \\
\hline & $(\mathrm{d} q)$ & 1 & & 4 & & & 4 & 1 & & & & 5 & & & 33.00 \\
\hline Iki & $(3)$ & & & & 1 & & 1 & & & & & & 1 & & 34.00 \\
\hline Nomozaki & $(\mathrm{n} q)$ & & & 2 & & & 1 & 1 & & & & 1 & 1 & & 33.50 \\
\hline Takarajima & $(0)$ & & & 1 & & & & 1 & & & & & 1 & & 34.00 \\
\hline Yoronto & $(\mathrm{d} q)$ & & & 1 & & & 1 & & & & & 1 & & & 33.00 \\
\hline \multirow[t]{2}{*}{ Okinawajima } & $\left(0^{-1}\right)$ & & 17 & 7 & & 1 & 10 & 6 & & & 1 & 8 & 6 & & 33.33 \\
\hline & $(\mathrm{d} q)$ & & 10 & 0 & 1 & & 5 & 6 & & & 3 & 7 & 1 & & 32.82 \\
\hline \multirow[t]{2}{*}{ Ishigakijima } & $(0)$ & 2 & 12 & 2 & & & 8 & 6 & & & & 10 & 4 & & 33.29 \\
\hline & $(\mathrm{d} P)$ & 2 & & 9 & & & 8 & 3 & & & 1 & 8 & 2 & & 33.09 \\
\hline \multirow[t]{2}{*}{ Iriomotejima } & $(\hat{0})$ & & & 1 & & & & 1 & & & & & 1 & & 34.00 \\
\hline & (d (q) & & & 2 & & 1 & 1 & & & & 1 & 1 & & & 32.50 \\
\hline \multirow[t]{4}{*}{ Ogasawara } & $(0)$ & 1 & & 8 & & & & 7 & 2 & & & & 8 & & 34.11 \\
\hline & (P) & & & 5 & & & & 4 & 1 & & & & $4 \quad 1$ & & 34.20 \\
\hline & & \multicolumn{6}{|c|}{ Anal Soft Rays } & \multicolumn{3}{|c|}{$P_{1}$. Rays } & & \multicolumn{2}{|c|}{$\mathrm{P}_{2} \cdot$ Rays } & & \\
\hline & & 20 & 21 & 22 & 23 & $\bar{X}$ & & 27 & 28 & 29 & & $4 \quad 5$ & 6 & & \\
\hline \multirow[t]{3}{*}{ Shirahama } & $(\hat{0})$ & & 6 & 15 & 1 & 21.77 & & 1 & 21 & & & 2 & $2 \quad 18$ & & \\
\hline & $(\mathrm{n} P)$ & 1 & 10 & 6 & & 21.29 & & & 17 & & & 1 & 115 & & \\
\hline & $(\mathrm{d} p)$ & & 1 & 4 & & 21.80 & & & 4 & 1 & & & 5 & & \\
\hline $\mathrm{Iki}$ & $(\vec{o})$ & & & 1 & & 22.00 & & & 1 & & & & 1 & & \\
\hline Nomozaki & $(\mathrm{n} P)$ & & 2 & & & 21.00 & & & 2 & & & & 2 & & \\
\hline Takarajima & $(0)$ & & & 1 & & 22.00 & & & 1 & & & & 1 & & \\
\hline Yoronto & (do) & & & 1 & & 22.00 & & & 1 & & & & 1 & & \\
\hline \multirow[t]{2}{*}{ Okinawajima } & $\left(0^{x}\right)$ & & 3 & 12 & 2 & 21.94 & & & 17 & & & 1 & 115 & & \\
\hline & (d이 & 2 & 4 & 5 & & 21.27 & & & 11 & & & & $1 \quad 10$ & & \\
\hline \multirow[t]{2}{*}{ Ishigakijima } & $(0)$ & 3 & 9 & 2 & & 20.93 & & & 14 & & & & 14 & & \\
\hline & (dq) & 1 & 5 & 5 & & 21.36 & & 1 & 10 & & & & 11 & & \\
\hline \multirow[t]{2}{*}{ Iriomotejima } & $\left(0^{-}\right)$ & 1 & & & & 20.00 & & & 1 & & & & 1 & & \\
\hline & (dq) & & 1 & 1 & & 21.50 & & & 2 & & & & 2 & & \\
\hline \multirow[t]{2}{*}{ Ogasawara } & $(\pi)$ & & & 8 & 1 & 22.11 & & & 9 & & & & 9 & & \\
\hline & (P) & & & 5 & & 22.00 & & 1 & 4 & & & & 5 & & \\
\hline
\end{tabular}

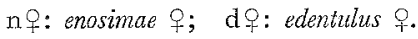




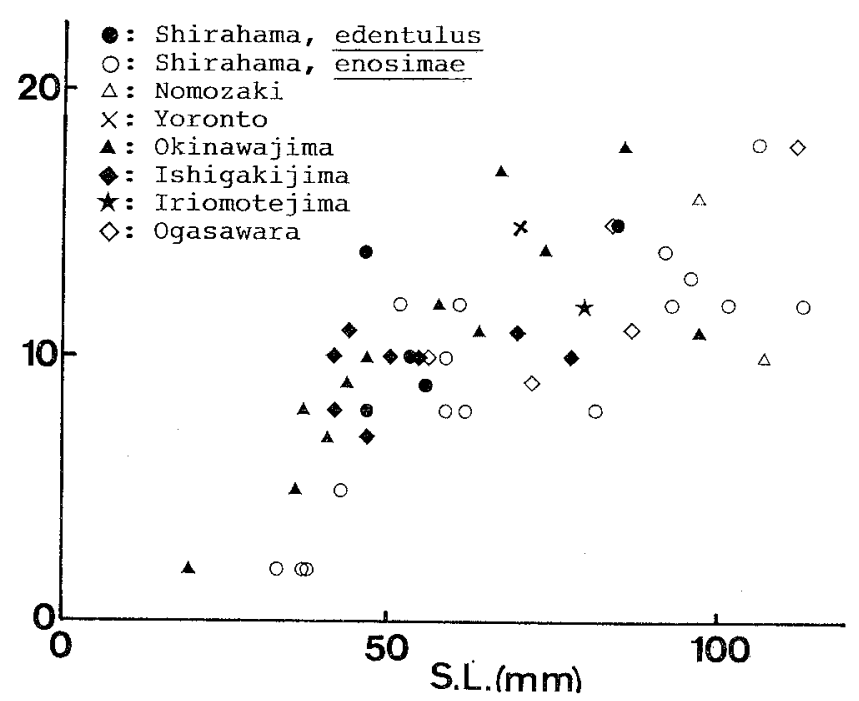

Fig. 18. The number of nasal cirri in female of Istiblennius edentulus.

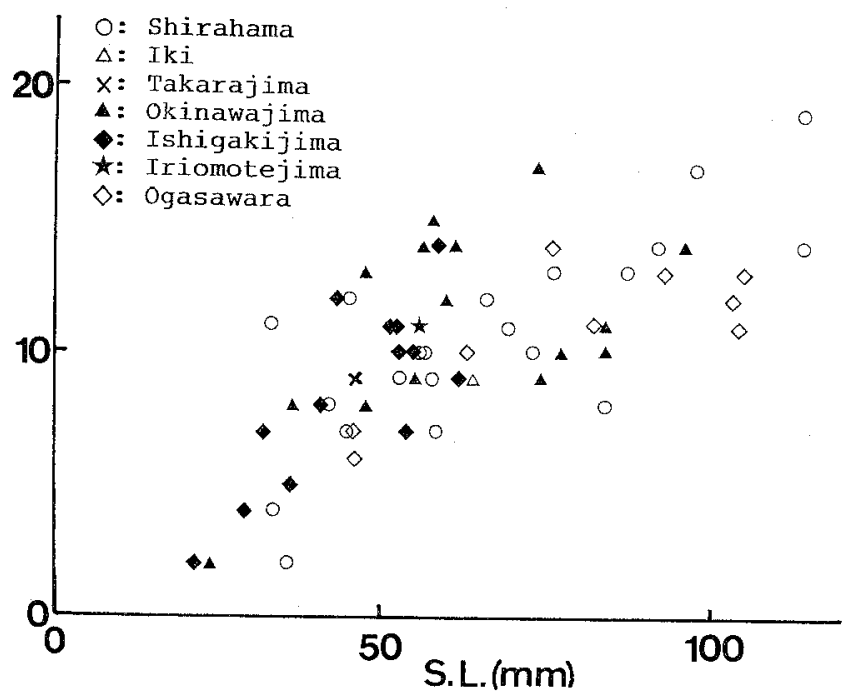

Fig. 19. The number of nasal cirri in males of Istiblennius edentulus.

crest; S: small crest; $\mathrm{M}$ : moderate crest; L: large crest). All the larger females (over $40 \mathrm{~mm}$ SL) from Okinawajima and from Ishigakijima have no crest and have edentulus type coloration. The populations of these localities, therefore, are believed to be edentulus form and the distinct female color pattern may develop after they attain ca. $40 \mathrm{~mm}$ in SL. In Shirahama, apparently both forms coexist. However, the large majority of females found in Shirahama are the enosimae form. Similar to the case of Entomacrodus thalassinus, I believe that the geographical isolation between these two forms was once established and now the edentulus form barely emigrate to the southern part of habitat of enosimae form on the Kuroshio Current. 


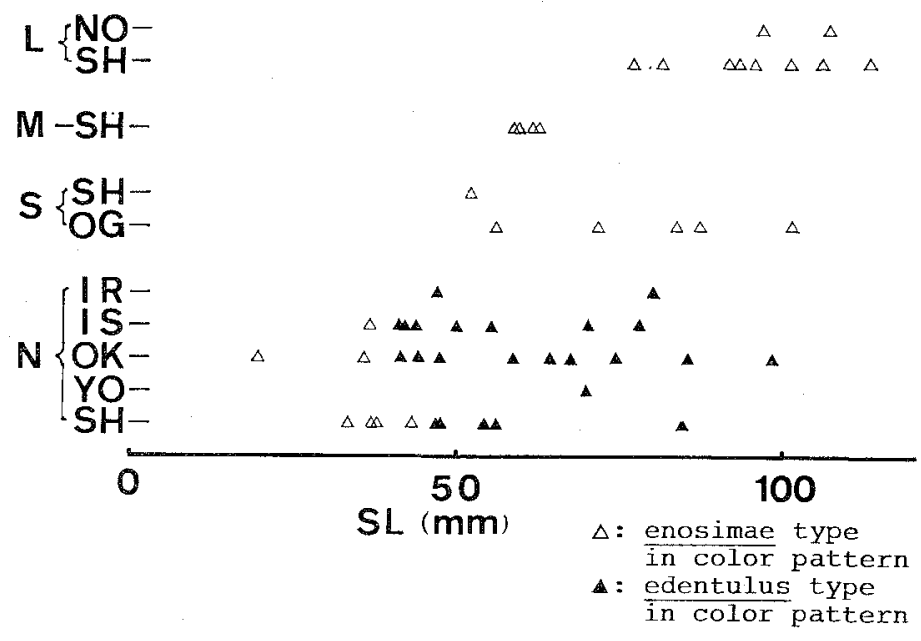

Fig. 20. The degree of development of crest in females of Istiblennius edentulus. $\mathrm{N}$ : no crest; $\mathrm{S}$ : small crest; $\mathrm{M}$ : moderate crest; $\mathrm{L}$ : large crest. SH: Shirahama; YO: Yoronto; OK: Okinawajima; IS: Ishigakijima; IR: Iriomotejima; OG: Ogasawara; NO: Nomozaki.

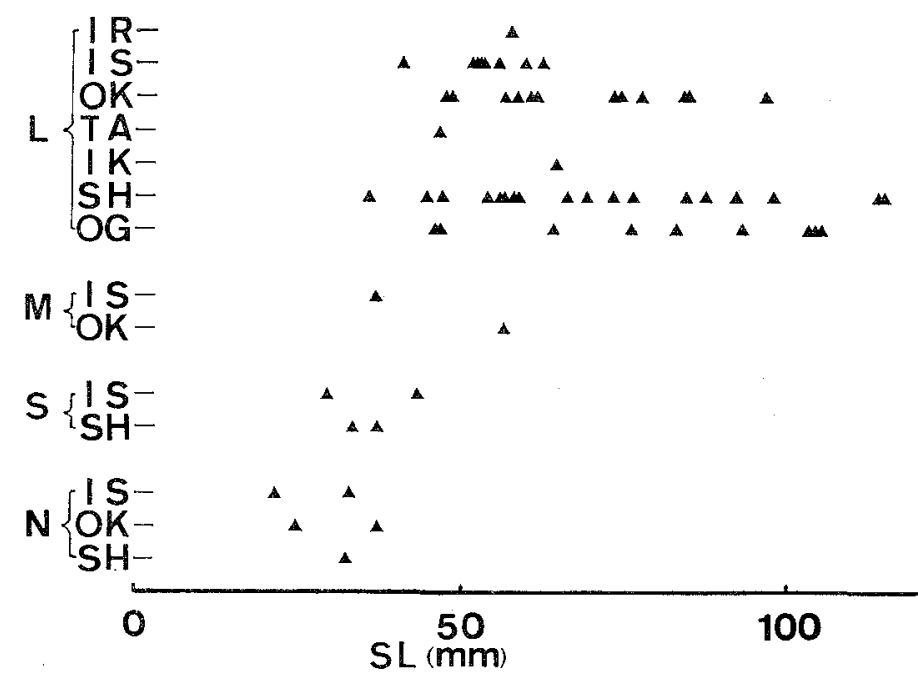

Fig. 21. The degree of development of crest in males of Istiblennius edentulus. $\mathrm{N}$ : no crest; S: small crest; $\mathrm{M}$ : moderate crest; L: large crest. SH: Shirahama; OK: Okinawajima; IS: Ishigakijima; OG: Ogasawara; IK: Iki; TA: Takarajima; IR: Iriomotejima.

In the female of enosimae, the crest commences to develop after they attain ca. $50 \mathrm{~mm}$ in SL and fully developed at the size of ca. $70 \mathrm{~mm}$ in SL. All the females from Ogasawara have crest, but it is small even in the specimens over $70 \mathrm{~mm}$ in SL. The Ogasawara population may possibly be the third form.

In the males of these forms, the crest commences to develop after they attain ca. $30 \mathrm{~mm}$ in SL and fully developed at ca. $40 \mathrm{~mm}$ in SL (Fig. 21). No significant 
difference could be noticed among males of these three forms in the present study.

The modal numbers of dorsal and anal ray counts are different between males and enosimae type females from Shirahama (Table 12). Those of edentulus type from Shirahama are the same as males (Table 12). Most of males from Shirahama are believed to be enosimae. Sexual dimorphism in these characters is also known in some populations of Ecsenius (Springer, 1971). In specimens from Okinawajima and from Ishigakijima, the anal fin ray counts also appeared to be somewhat different between the sexes (Table 12). However, it is in the inverse trend between these two localities. The further study is desirable in the sexual dimorphism of 1 . edentulus. Both sexes of Ogasawara specimens have higher dorsal and anal ray counts. This may support the idea that the population of the Ogasawara Islands is the third form.

This species occurred from moderately to very exposed rocky reefs. In the moderately exposed reefs, they are dominant in the intertidal zone and abundantly found in tide pools. At low tide, they were also abundantly found on upper subtidal rocky reefs, sometimes extending under $1 \mathrm{~m}$ deep but never found over about $2 \mathrm{~m}$ deep. Spawnings were observed to occur from middle May to middle September. They were found all the year round. I. e. edentulus seems to prefer tide pools more than enosimae does, since all the females of edentulus were observed in tide pools. The possibilities of the reproduction and the overwintering of edentulus in the study area are unknown.

Distribution: I. e. edentulus -East Africa, Red Sea, Indian Ocean, western and central Pacific. I. e. enosimae -southern Japan and Korea.

Japanese localities: I. e. edentulus - Shirahama (Wakayama Pref.), Kochi Pref., Nomozaki (Nagasaki Pref.), Nakanoshima Island, Amami Islands and Yoronto Island (Kagoshima Pref.), Okinawa Islands, Miyako Island and Yaeyama Islands (Okinawa Pref.). I. e. enosimae -Jogashima, Misaki and Enoshima (Kanagawa Pref.), Izu Peninsular (Shizuoka Pref.), Shirahama (Wakayama Pref.), Seto Inland Sea, Kochi Pref., Amakusa (Kumamoto Pref.), Nomozaki, Iki Island, Tsushima Island, Goto Islands and Danjo Islands (Nagasaki Fref.), Yakushima Island, Tanegashima Island, Takarajima Island? and Amami Islands? (Kagoshima Pref.).

25. Istiblennius lineatus (Valenciennes, 1836)

Japanese name: Sen-kaeruuo (Fig. 28-R)

Common species. Twenty males (26.1-75.0 mm SL), 15 females (27.8-65.8 $\mathrm{mm} \mathrm{SL)} \mathrm{and} 7$ youngs $(18.2-24.0 \mathrm{~mm} \mathrm{SL})$ were examined. Dorsal fin rays XIII or XIV, 20 to 24; anal fin rays II, 21 to 25 ; pectoral fin rays 13 to 15 ; pelvic fin rays 3 ; principal caudal fin rays 13 ; nasal cirri 1 to 5 ; orbital cirri 1 to 11 ; crest on head in male and no crest on head in female.

Compared specimens -Okinawajima Island (Okinawa Pref.): 9 males (32.6-76.0) and 11 females (29.1-83.2); Ishigakijima Island (Okinawa Pref.): 10 males (33.0-84.0), 9 females (32.269.8) and 3 youngs (19.7-28.0); Iriomotejima Island (Okinawa Pref.): 2 males (60.2 and 65.2) and 1 female (37.2).

Some meristic characters are shown in Table 13, Figs. 22 and 23. The modal number of soft dorsal fin rays and anal fin rays were different between Shirahama specimens and the compared specimens (Table 13). Except for the above, no significant difference was noticed between Shirahama specimens and the compared specimens. 
This species occurred from moderately to very exposed rocky reefs. Most of them were found in small shallow tide pools which were highly placed in the intertidal zone. The other blenniid species seldom occurred in these pools. Spawnings could not be observed in the present study. Any morphological sign associated with reproduction also could not be found in Shirahama specimens examined. In December of 1972 and January of 1973, many killed and nearly killed individuals were found. in small, shallow and highly-placed tide pools. The water temperature of these pools might be heavily affected by the ambient air temperature and 4 to $8^{\circ} \mathrm{C}$ lower than that of outer sea water at the observations conducted in the morning. Although fairly abundant youngs were recruited from late June to late October, they could not be found in spring time in this study. Almost all of them seems not to be able to survive over the cold season. Their habit, living in highly-placed, shallow and

Table 13. Frequency distributions for some meristic characters in Istiblennius lineatus.

\begin{tabular}{|c|c|c|c|c|c|c|c|c|c|c|c|c|c|c|c|c|}
\hline & \multicolumn{16}{|c|}{ Dorsal Fin } \\
\hline & \multicolumn{3}{|c|}{ Spines } & \multicolumn{6}{|c|}{ Soft Rays } & \multicolumn{7}{|c|}{ Total Elements } \\
\hline & XIII & I $X$ & IV & & 20 & 21 & 22 & 23 & 24 & & 33 & 34 & 35 & 36 & 37 & $\overline{\mathrm{x}}$ \\
\hline Shirahama & 39 & & 3 & & 1 & 3 & 14 & 19 & 5 & & 1 & 2 & 13 & 21 & 5 & 35.64 \\
\hline Okinawajima & 19 & & 1 & & & & 11 & 6 & 3 & & & & 10 & 7 & 3 & 35.65 \\
\hline Ishigakijima & 22 & & & & & & 11 & 10 & 1 & & & & 11 & 10 & 1 & 35.55 \\
\hline \multirow[t]{3}{*}{ Iriomotejima } & 3 & & & & & & & 2 & 1 & & & & & 2 & 1 & 36.33 \\
\hline & \multicolumn{8}{|c|}{ Anal Soft Rays } & \multicolumn{5}{|c|}{ Pectoral Rays } & & & \\
\hline & 21 & 22 & 23 & 24 & 25 & & $\overline{\mathrm{X}}$ & & 26 & 27 & 28 & 29 & 30 & & & \\
\hline Shirahama & 1 & 1 & 17 & 16 & 7 & & 3.64 & & 2 & 2 & 37 & & 1 & & & \\
\hline Okinawajima & & & 6 & 12 & 2 & & .80 & & 3 & 2 & 15 & & & & & \\
\hline Ishigakijima & & & 7 & 14 & 1 & & 3.73 & & 1 & 1 & 19 & & 1 & & & \\
\hline Iriomotejima & & & & 2 & 1 & & .33 & & & & 3 & & & & & \\
\hline
\end{tabular}

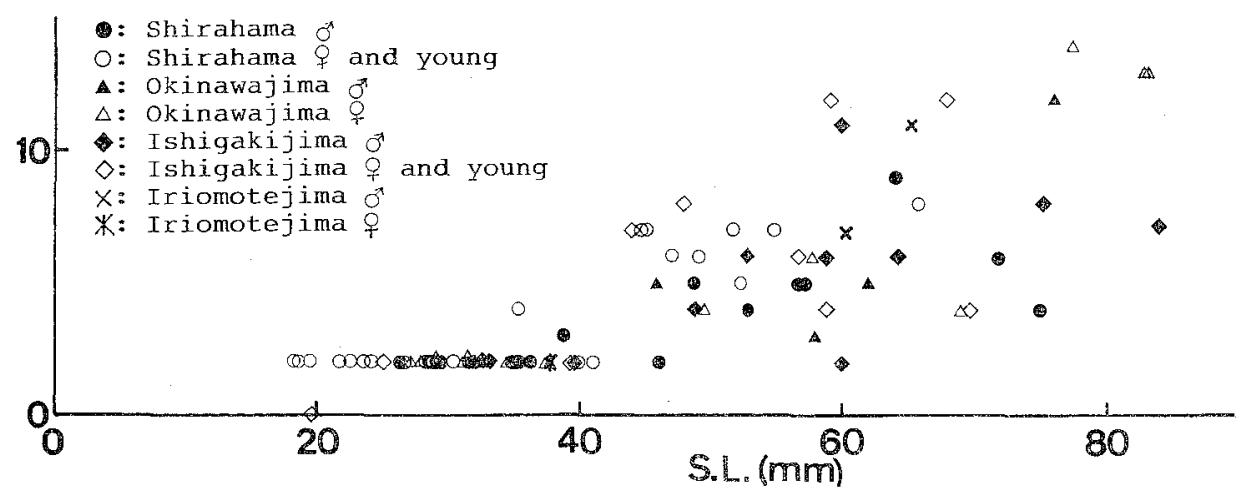

Fig. 22. The number of nasal cirri in Istiblennius lineatus. 


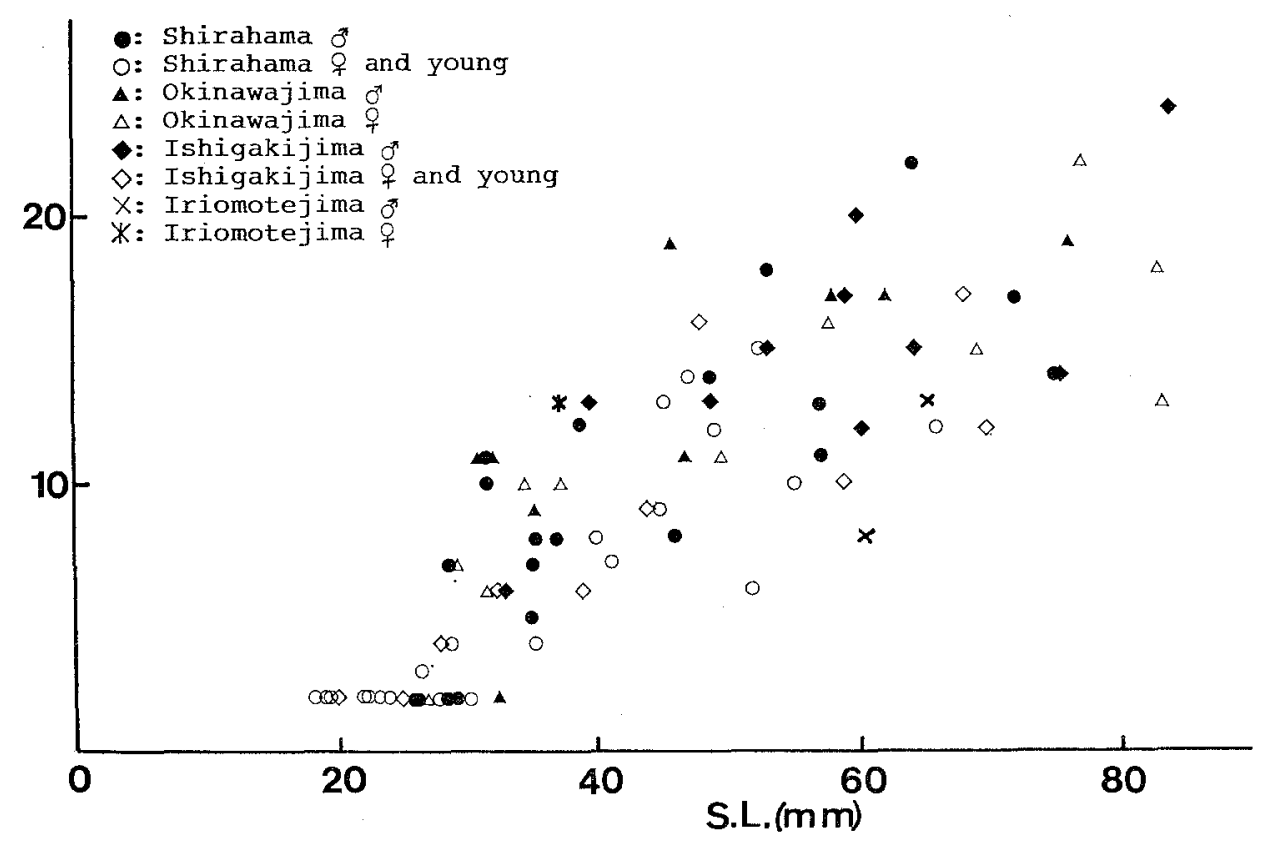

Fig. 23. The number of orbital cirri in Istiblennius lineatus.

small tide pools, may largely aggravate the survivorship of them in the cold season of the study area.

Distribution: Red Sea, Persian Gulf, Indian Ocean, western and central Pacific.

Japanese localities: Shirahama (Wakayama Pref.), Kochi Pref., Danjo Islands (Nagasaki Pref.), Yakushima Island, Tanegashima Island and Amami Islands (Kagoshima Pref.), Okinawa Islands and Yaeyama Islands (Okinawa Pref.).

26. Mimoblennius atrocinctus (Regan, 1909)

Japanese name: Matsuba-ginpo (Fig. 28-S)

Rare species. Three females (37.0-40.1 mm SL) were examined. Dorsal fin rays XIII, 17 or 18; anal fin rays II, 20 or 21 ; pectoral fin rays 14 or 15 ; pelvic fin rays 2 ; principal caudal fin rays 13 ; nasal cirri 2 to 4 ; orbital cirri 2 ; nuchal cirrus simple.

Compared specimens -Okinawa Islands (Okinawa Pref.): 3 males (28.8-48.1); Ogasawara Islands (Tokyo Pref.): 3 males (40.1-44.4) and 1 female (35.3).

Some meristic characters are shown in Table 14. Besides the meristic characters, a subtle difference was noticed in the configuration of nasal cirri between Shirahama specimens and the compared specimens. Nasal cirri of Shirahama specimens are rather palmate as a whole (Fig. 24-b, c, d) as described by Smith-Vaniz and Springer (1971). Whereas those of the compared specimens (including 1 female) are slender and deeply incised between cirri (Fig. 24-a) as shown in Fig. 10 of Springer \& Spreitzer (1978) which was illustrated after a fish from Taiwan. According to the original description of Regan (1909), a single specimen from Christmas Island has a bifid nasal tentacle and no nuchal tentacles. Smith-Vaniz \& Springer (1971) 
Table 14. Frequency distributions for some meristic characters in Mimoblennius atrocinctus.

\begin{tabular}{|c|c|c|c|c|c|c|c|c|c|c|c|c|c|c|c|c|c|c|c|c|c|c|c|}
\hline & \multicolumn{7}{|c|}{ Dorsal Soft Rays } & \multicolumn{6}{|c|}{ Anal Soft Rays } & \multicolumn{6}{|c|}{ Pectoral Rays } & & & & \\
\hline & 17 & & 18 & 19 & & $\overline{\mathrm{X}}$ & & 20 & 21 & 22 & & $\overline{\mathrm{x}}$ & & 27 & 28 & & 29 & 30 & & & & & \\
\hline Shirahama & & & 2 & & & 7.66 & & 1 & 2 & & & .66 & & & 2 & & & 1 & & & & & \\
\hline Okinawa & & & 2 & 2 & & 8.50 & & 1 & & 2 & & .33 & & & 3 & & & & & & & & \\
\hline \multirow[t]{3}{*}{ Ogasawara } & & & & 3 & & 9.00 & & & 2 & 2 & & .50 & & 1 & 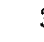 & & & & & & & & \\
\hline & \multicolumn{5}{|c|}{ Nasal Cirri } & \multicolumn{3}{|c|}{ Orbital Cirri } & \multicolumn{8}{|c|}{ Nuchal Cirri } & \multicolumn{7}{|c|}{ PTALLP } \\
\hline & 4 & 5 & 6 & 7 & 8 & 3 & 4 & 5 & 2 & 3 & 4 & 5 & 6 & 7 & 8 & 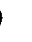 & 6 & 7 & 8 & 9 & 10 & 11 & 12 \\
\hline Shirahama & 1 & 1 & & & 1 & & 3 & & 2 & & & & 1 & & & & & & & 1 & 1 & 1 & \\
\hline Okinawa & 2 & 1 & & & & & 3 & & 1 & & & & 1 & & 1 & & 1 & & & & & 1 & 1 \\
\hline Ogasawara & 3 & & & 1 & & 1 & 2 & 1 & 1 & & & 2 & & & & . & 1 & & 1 & 1 & 1 & & \\
\hline
\end{tabular}

PTALLP: position of terminal anterior lateral line pore (given as dorsal fin elements under which the pore located).

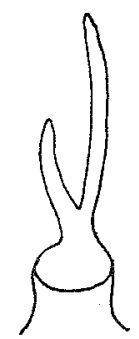

a

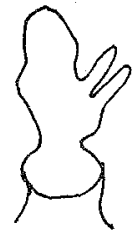

b

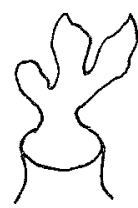

C
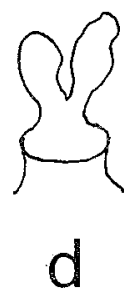

Fig. 24. The typical nasal cirri configuration of Mimoblennius atrocinctus.

described that nuchal cirri are palmate. On the other hand, Fig. 10 of Springer \& Spreitzer (1978) shows it is simple. Both conditions were observed in Shirahama specimens and the compared specimens.

This species occurred only on very exposed rocky reefs. All fishes observed occupied empty shells of Balanus tintinnablum volcano on upper subtidal zone. On June 28, 1975, a pair was observed in a empty shell of $B . t$. volcano. The male protruded his head out of the aperture and the female was fully in the empty shell. The male did not easily leave the shell when frightened and returned sooner after the crisis passed. The female did not return to the shell after she was driven away. The black markings on throat and the reddish ocellus on the membrane between 1 st and 2nd dorsal fin of the male were much more conspicuous than others observed. Although the egg mass could not be found in the shell, above noted observation indicate that the reproduction may possibly rarely occur in the study area.

Distribution: Ceylon, Christmas Island (Indian Ocean), Dampier Archipelago (Australia), Hong Kong, Taiwan, Japan.

Japanese localities: Shirahama (Wakayama Pref.), Okinawa Islands (Okinawa Pref.), Ogasawara Islands (Tokyo Pref.). 
27. Praealticus margaritarius (Snyder, 1908)

Japanese name: Tama-ginpo (Fig. 28-T)

Rather rare species. Four males $(40.8-53.8 \mathrm{~mm} \mathrm{SL})$ and 5 females $(40.0-50.8 \mathrm{~mm} \mathrm{SL})$ were examined. Dorsal fin rays XIII, 16 to 19; anal fin rays II, 17 to 20 ; pectoral fin rays 15 or 16 ; pelvic fin rays 2 to 4 ; principal caudal fin rays 13 ; nasal cirri 1 or 2 (mostly simple); orbital cirri 3 to 12 ; in both sexes, crest on head, but smaller in female than in male.

Compared specimens - Takarajima Island (Kagoshima Pref.): 1 male (27.0) and 1 female (35.3); Yoronto Island (Kagoshima Pref.): 2 males (42.8 and 49.5); Okinawajima Island (Okinawa Pref.): 7 males (28.1-64.1) and 17 females (25.8-59.0); Ishigalijima Island (Okinawa Pref.): 9 males $(33.2-52.9)$ and 7 females $(21.8-45.2)$.

Some meristic characters are shown in Table 15 and Fig. 25. The modal number of soft dorsal fin rays and anal fin rays in specimens from Shirahama are 18 and 19, respectively, while those from Okinawajima and Ishigakijima are 19 and 20, respectively.

All individuals observed in the present study were found in tide pools which are shallow, small and rather highly-placed in the intertidal zone of moderately to very exposed rocky reefs. Three females collected on 28 June, 1973 and 1 female collected on 2 August, 1973 have conspicuously swollen abdomen and 1 male collected on 28 June, 1973 has the spatulated tips on anterior 4 anal soft rays. These facts indicate that the reproduction may occur in the study area, at least, in the summer subsequent to the mild winter, although the egg masses could not be found.

Distribution: southern Japan.

Japanese localities: Shirahama (Wakayama Pref.), Kochi Pref., Yakushima Island, Tanegashima Island, Takarajima Island, Kikaijima Island and Yoronto Island (Kagoshima Pref.), Okinawajima Island and Ishigakijima Island (Okinawa Pref.).

Table 15. Frequency distributions for some meristic characters in Praealticus margaritarius.

\begin{tabular}{|c|c|c|c|c|c|c|c|c|c|c|c|c|c|c|c|c|c|}
\hline & \multicolumn{17}{|c|}{ Dorsal Fin } \\
\hline & \multicolumn{3}{|c|}{ Spines } & \multicolumn{6}{|c|}{ Soft Rays } & \multicolumn{8}{|c|}{ Total Flements } \\
\hline & XII & & III & & 16 & 17 & 18 & 19 & 20 & & 9 & 30 & 31 & 32 & 33 & & $\bar{x}$ \\
\hline Shirahama & & & 9 & & 1 & 1 & 6 & 1 & & & 1 & 1 & 6 & 1 & & & 0.70 \\
\hline Takarajima & & & 2 & & & 1 & 1 & & & & & 1 & 1 & & & & 0.50 \\
\hline Yoronto & & & 2 & & & & 2 & & & & & & 2 & & & & 1.00 \\
\hline Okinawajima & 1 & & 23 & & & & 9 & 15 & & & & & 10 & 14 & & & 1.58 \\
\hline \multirow[t]{3}{*}{ Ishigakijima } & & & 16 & & & & 4 & 11 & 1 & & & & 4 & 11 & 1 & & 1.81 \\
\hline & \multicolumn{7}{|c|}{ Anal Soft Rays } & \multicolumn{5}{|c|}{ Pectoral Rays } & \multicolumn{5}{|c|}{ Pelvic Rays } \\
\hline & 17 & 18 & 19 & 20 & 21 & $\bar{Y}$ & $\bar{x}$ & 29 & 30 & 31 & 32 & & 4 & 5 & 6 & 7 & 8 \\
\hline Shirahama & 1 & & 5 & 3 & & 19 & .11 & & 8 & 1 & & & & 1 & 1 & 1 & 6 \\
\hline Takarajima & & & & 2 & & 20. & .00 & & 2 & & & & 1 & 1 & & & \\
\hline Yoronto & & & 2 & & & 19. & .00 & & 2 & & & & & & & & 2 \\
\hline Okinawajima & & & 4 & 18 & 2 & 19. & .92 & 1 & 21 & & 2 & & & & 1 & 5 & 18 \\
\hline Ishigakijima & & & 3 & 10 & 3 & 20. & .00 & 2 & 14 & & & & & & & 2 & 14 \\
\hline
\end{tabular}




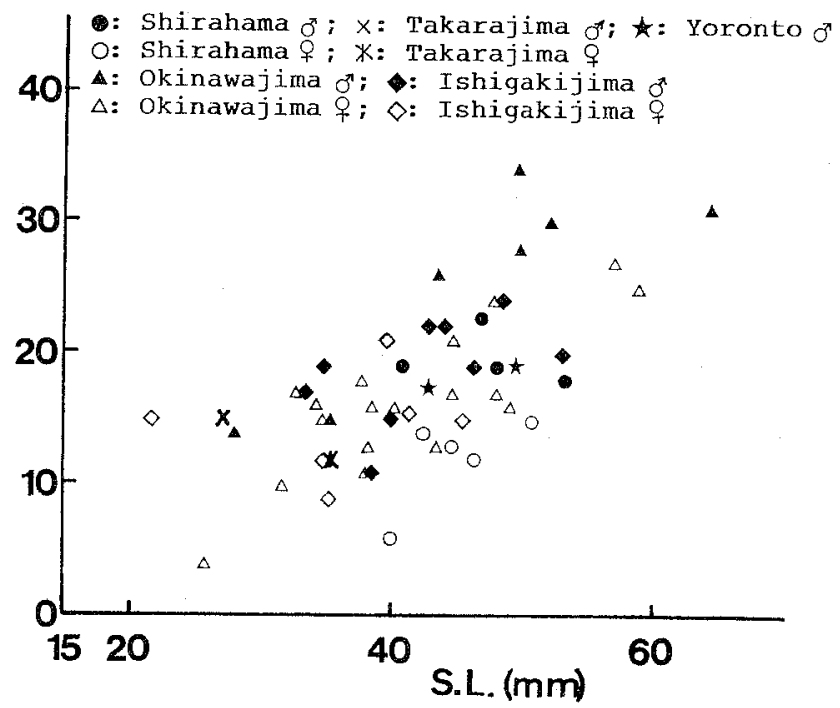

Fig. 25. The number of orbital cirri in Praealticus margaritarius.

28. Praealticus amboinensis tanegasimae (Jordan et Starks, 1906)

Japanese name: Tane-ginpo (Fig. 28-U)

Common species. Thirteen males $(30.0-87.7 \mathrm{~mm} \mathrm{SL})$ and 17 females $(44.8-81.0 \mathrm{~mm} \mathrm{SL})$ were examined. Dorsal fin rays XIII, 17 to 19; anal fin rays II, 18 to 20; pectoral fin rays 14 to 16 ; pelvic fin rays 3 or 4; principal caudal fin rays 13; nasal cirri 1 to 3 (mostly simple); orbital cirri 1 to 34 (mesial and lateral short cirri on a main cirrus); in adult (over $40 \mathrm{~mm} \mathrm{SL}$ ), both sexes have crest on head, but smaller in female than in male, sometimes rudimentary in female.

Compared specimens - Hachijojima Island (Tokyo Pref.): 4 males (57.2-82.1) and 4 females (47.1-66.9); Okinawajima Island (Okinawa Pref.): 11 males (27.1-78.6) and 8 females (25.1-57.3).

Some meristic characters are shown in Table 16 and Fig. 26. The average

Table 16. Frequency distributions for some meristic characters in Praealiticus amboinensis tanegasimae.

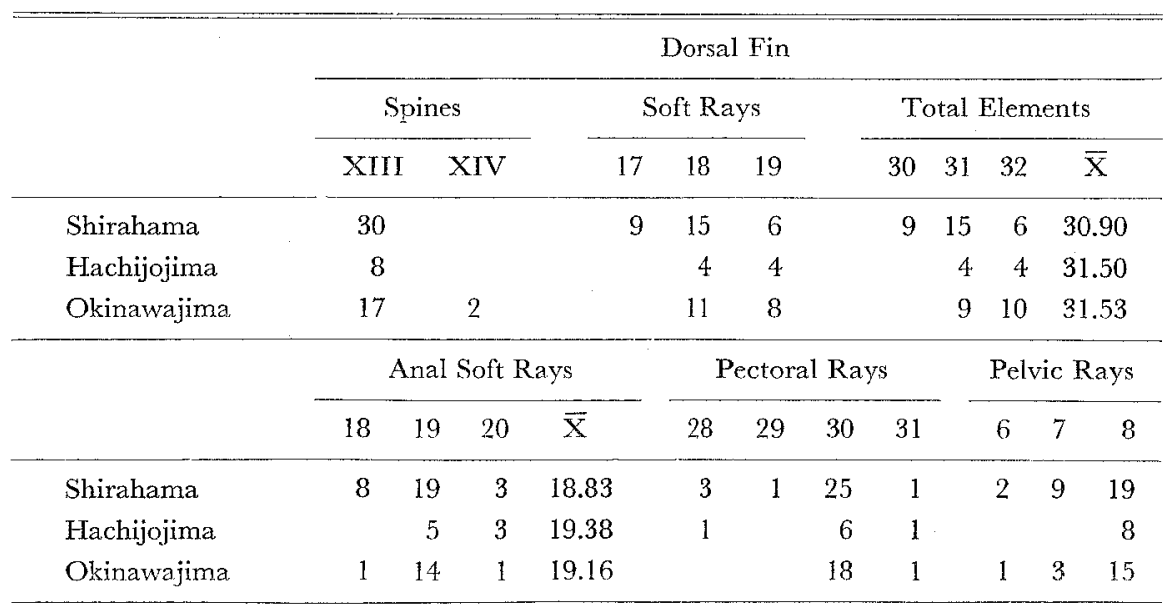




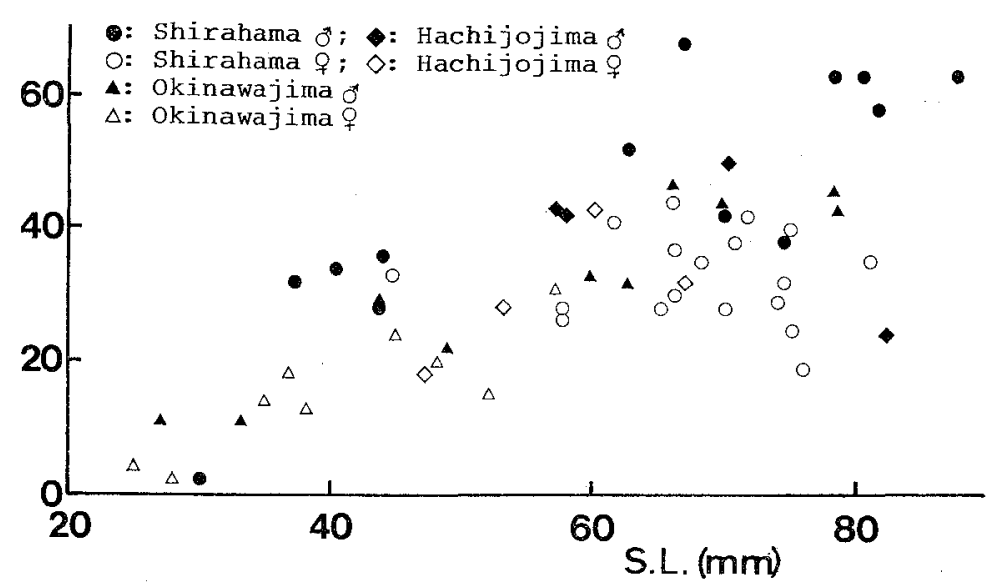

Fig. 26. The number of orbital cirri in Praealticus amboinensis tanegasimae.

numbers of soft dorsal rays and anal rays in Shirahama population are slightly lower than those in Hachijojima and Okinawajima population. Following Schultz \& Chapman (1960), present study treated this form as one of the three subspecies of Praealticus amboinensis.

This species occurred on moderately to very exposed rocky reefs. Most of them were found in tide pools. They are appeared to prefer the pools moderately to rather highly-placed in the intertidal zone. An egg mass guarded by a male was observed in a hole of the vertical wall in a tide pool on 4 July, 1977. They were found all the year round in the study area.

Distribution: southern Japan.

Japanese localities: Shizuoka Pref., Shirahama (Wakayama Pref.), Kochi Pref., Nomozaki and Danjo Islands (Nagasaki Pref.), Yakushima Island, Tanegashima Island and Amami Islands (Kagoshima Pref.), Okinawa Islands and Miyakojima Island (Okinawa Pref.), Hachijojima Island and Ogasawara Islands? (Tokyo Pref.).

29. Rhabdoblennius ellipes (Jordan et Snyder, 1906)

Japanese name: Rosoku-ginpo (Fig. 28-V)

Rather rare species. Five males (47.8-57.0 mm SL), 5 females (39.9-56.0 mm SL) and 1 young ( $15.6 \mathrm{~mm} \mathrm{SL}$ ) were examined. Dorsal fin rays XII, 19 or 20; anal fin rays II, 18 to 22 ; pectoral fin rays 13 or 14; pelvic fin rays 3 ; principal caudal fin rays 13; nasal cirrus simple; orbital cirrus simple.

Compared specimens --Takarajima Island (Kagoshima Pref.): 1 male (48.0); Yoronto Island (Kagoshima Pref.): 2 males (41.5 and 56.3) and 1 female (54.8); Okinawajima Island (Okinawa Pref.): 5 males (33.1-47.9) and 5 females (30.3-40.6); Ishigakijima Island (Okinawa Pref.): 6 males $(28.2-44.9), 1$ female (29.8) and 2 youngs (17.4 and 21.3$)$.

Some meristic characters are shown in Table 17. No significant difference was noticed between Shirahama specimens and the compared specimens.

This species occurred on moderately to very exposed rocky reefs, sometimes found in shallow tide pools rather highly-placed in intertidal zone. Two females (48.9 and $56.0 \mathrm{~mm} \mathrm{SL)} \mathrm{collected} \mathrm{in} \mathrm{July,} 1973$ have the conspicuously swollen 
Table 17. Frequency distributions for some meristic characters in Rhabdoblennius ellipes.

\begin{tabular}{|c|c|c|c|c|c|c|c|c|c|c|c|c|c|c|c|c|}
\hline & \multicolumn{4}{|c|}{ Dorsal Soft Rays } & \multicolumn{6}{|c|}{ Anal Soft Rays } & \multicolumn{2}{|c|}{$P_{1}$. Rays } & \multicolumn{4}{|c|}{ PTALLP } \\
\hline & 19 & 20 & 21 & $\overline{\mathrm{X}}$ & 18 & 19 & 20 & 21 & 22 & $\overline{\mathrm{X}}$ & 27 & 28 & 4 & 5 & 6 & 7 \\
\hline Shirahama & 3 & 7 & & 19.70 & 1 & & 1 & 7 & 1 & 20.70 & 1 & 9 & & 1 & 6 & 3 \\
\hline Takarajima & & 1 & & 20.00 & & & & & 1 & 22.00 & & 1 & & & & 1 \\
\hline Yoronto & & 3 & & 20.00 & & & & 3 & & 21.00 & & 3 & & & 3 & \\
\hline Okinawajima & 3 & 6 & 1 & 19.80 & & & & 7 & 3 & 21.30 & & 10 & 1 & 1 & 6 & 2 \\
\hline Ishigakijima & 2 & 7 & & 19.78 & & & 1 & 7 & 1 & 21.00 & & 9 & & 2 & 5 & 1 \\
\hline
\end{tabular}

PTALLP: position of terminal anterior lateral line pore (given as dorsal fin elements under which the pore located).

abdomen and a male ( $49.9 \mathrm{~mm}$ SL) collected on $15 \mathrm{July}, 1973$ has the spatulated tips of anal soft rays. These facts indicate that the reproduction may occur, at least, in the summer subsequent to the mild winter, although no egg mass could be found in the present study. In the case of mild winter, they may also survive over the cold season in the study area.

Distribution: southern Japan.

Japanese localities: Mie Pref., Shirahama (Wakayama Pref.), Kochi Pref., Nomozaki (Nagasaki Pref.), Yakushima Island, Tanegashima Island, Takarajima Island, Nakanoshima Island, Kikaijima Island, Amami-Oshima Island and Yoronto Island (Kagoshima Pref.), Okinawa Islands, Ishigakijima Island and Hatoma Island (Okinawa Pref.).

30. Salarias luctuosus Whitley, 1929

Japanese name: Shima-ginpo (Fig. 28-W)

Rare species. One male $(69.7 \mathrm{~mm} \mathrm{SL})$ was examined. Dorsal fin rays XII, 19; anal fin rays II, 20 ; pectoral fin rays 14; pelvic fin rays 2; principal caudal fin rays 13 ; nasal cirrus slightly serrated on contour; orbital cirrus simple; nuchal cirrus simple.

Compared specimens -Okinawajima Island (Okinawa Pref.): 4 males (35.2-45.8) and 6 females (30.0-50.0); Ishigakijima Island (Okinawa Pref.): 9 males (26.0-53.3) and 5 females (25.1 47.2); Iriomotejima Island (Okinawa Pref.): 1 male (43.1) and 1 female (41.1).

Some meristic characters are shown in Table 18. No significnat difference was noticed between Shirahama specimen and the compared specimens.

Table 18. Frequency distributions for some meristic characters in Salarias luctuosus.

\begin{tabular}{|c|c|c|c|c|c|c|c|c|c|c|c|c|c|c|c|c|c|c|}
\hline & \multicolumn{5}{|c|}{ Dorsal Soft Rays } & \multicolumn{5}{|c|}{ Anal Soft Rays } & \multicolumn{4}{|c|}{ Pectoral Rays } & \multicolumn{4}{|c|}{ PTALLP } \\
\hline & 17 & 18 & 19 & 20 & $\overline{\mathrm{x}}$ & 18 & 19 & 20 & 21 & $\overline{\mathrm{X}}$ & 26 & 27 & 28 & 29 & 7 & 8 & 9 & 10 \\
\hline Shirahama & & & 1 & & 19.00 & & & 1 & & 20.00 & & & 1 & & & & 1 & \\
\hline Okinawajima & & 2 & 8 & & 18.80 & 1 & 1 & 8 & & 19.70 & 1 & & 9 & & 1 & 1 & 6 & 2 \\
\hline Ishigakijima & 1 & 4 & 9 & & 18.57 & & 6 & 8 & & 19.57 & & 1 & 12 & 1 & & 3 & 8 & 3 \\
\hline Iriomotejima & & & 1 & 1 & 19.50 & & & 1 & 1 & 20.50 & & & 2 & & & & 1 & 1 \\
\hline
\end{tabular}

PTALLP: position of terminal anterior lateral line pore (given as dorsal fin elements under which the pore located). 
This species occurred on moderately exposed rocky reefs and seemed to prefer to shallow tide pools rather highly-placed in intertidal zone. A male collected on 23 May, 1973 was attained $69.7 \mathrm{~mm}$ SL that was the largest in the specimens examined. Therefore, he might survive over the cold season. He also had a bright red ocellus on membranes between 1st and 3rd dorsal spines and spatulated tips on 3rd to 19th anal soft rays. These characters indicate that the reproduction may occur in the study area, at least, in the summer subsequent to the mild winter.

Distribution: Japan to East Indies.

Japanese localities: Shirahama (Wakayama Pref.), Kochi Pref., Yakushima Island, Tanegashima Island and Kikaijima Island (Kagoshima Pref.), Okinawa Islands, Miyakojima Island and Yaeyama Islands (Okinawa Pref.).

\section{Discussion}

In the present study, 32 species including subspecies were found. Twenty-three species or subspecies of these are shown in Figs. 27 and 28. The study area is climatically warm temperatre and located at the peripheral in the distribution of the family Blenniidae which flourishes in tropical waters.

On the fish fauna of the study area, Kuwamura (1980) reported that the number of species increased in summer and autumn, but decreased in winter and that juveniles of smaller tropical fishes are seemingly transported to this area by the warm Kuroshio Gurrent from southern areas, and very rarely survive over winter. According to seasonal occurrence, Kuwamura (1980) grouped the fishes observed in the study area into four types: 1) Year-round resident species (Y-type); 2) species which reside all the year round in years of warm winter waters, but appear only as juveniles from July to January in years of cold winter waters (Ya-type); 3) species of which only juveniles appear almost restricted to the period from July to January (A-type); and 4) speices which appear both as adults and juveniles only in the warmer period from May to November (S-type).

As the observations were not regularly conducted, the precise seasonal occurrence of these blenniids could not be presented in this study. The possibility of overwintering, however, could be estimated by the fragmental observations, the size of fishes, the geographical distribution of each species and so on. Table 19 summarized the abundance, the possibility of overwintering and of reproduction of each species in the study area.

Ten species (No. 1 to 10 in Table 19) may be safely assigned to Y-type of Kuwamura (1980). Judging from the three ecological aspects shown in Table 19, the populations of these species are believed to be stable and perfect (most of individuals may be native). Four (No. 1, and 5 to 7 in Table 19) of these species are absent in the Okinawa Islands (subtropics) and 6 species (No. 4 to 8, and 10 in Table 19) are almost restricted to southern Japan in distribution. A rare species, $O$. fasciolatoceps (No. 20 in Table 19) is also believed to establish a stable (native) population, because the study area is located at the center of geographical distribution of the species 

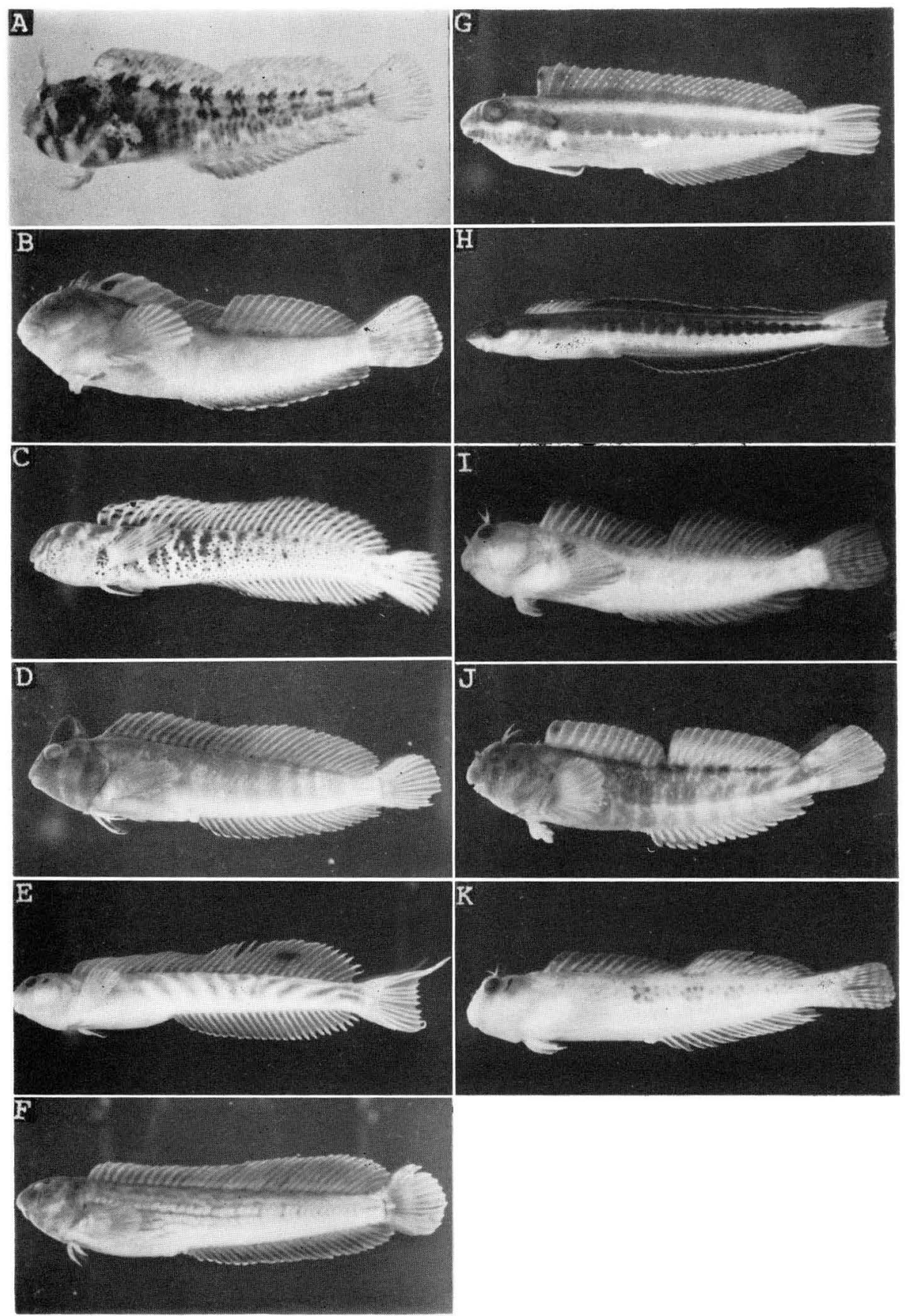

Fig. 27. Blenniid fishes collected in Shirahama I. A: Pictiblennius yatabei; B: Scartella cristata; C: Omobranchus elegans; D: Omobranchus fasciolatoceps; E: Omobranchus loxozonus; F: Omobranchus punctatus; G: Petroscirtes (Dasson) breviceps; H: Plagiotremus tapeinosoma; I: Entomacrodus caudofasciatus; J : Entomacrodus stellifer stellifer; $\mathrm{K}$ : Entomacrodus striatus. 

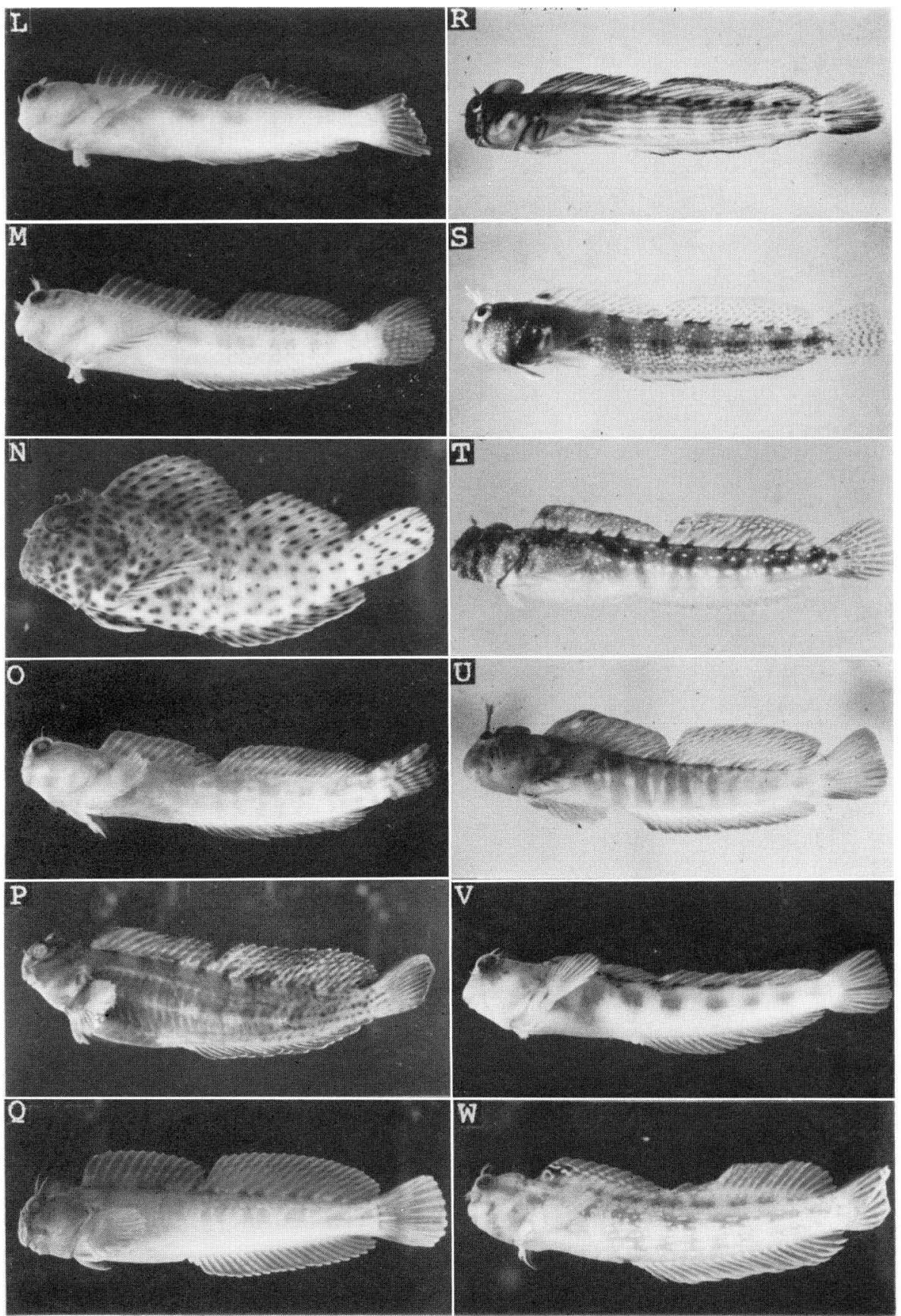

Fig. 28. Blenniid fishes collected in Shirahama II. L: Entomacrodus thalassinus thalassinus; M: Entomacrodus thalassinus longicirrus; N: Exallias brevis; $\mathrm{O}$ : Istiblennius bilitonensis; $\mathrm{P}$ : Istiblennius edentulus edentulus; Q: Istiblennius edentulus enosimae; R: Istiblennius lineatus; $\mathrm{S}$ : Mimoblennius atrocinctus; T: Praealticus margaritarius; U: Praealticus amboinensis tanegasimae; V: Rhabdoblennius ellipes; W: Salarias luctuosus. 
Table 19. The summary of the abundance, the possibility of overwintering and of reproduction in each species in the study area.

\begin{tabular}{|c|c|c|c|c|}
\hline No. & Species & Abundance & Overwinter & Reproduction \\
\hline 1. & Scartella cristata & A & + & + \\
\hline 2. & Omobranchus punctatus & A & + & +- \\
\hline & Petroscirtes breviceps & $\mathrm{A}$ & + & + \\
\hline 4. & Entomacrodus s. stellifer & A & + & + \\
\hline 5. & Istiblennius e. enosimae & A & + & + \\
\hline 6. & Pictiblennius yatabei & $\mathrm{C}$ & + & + \\
\hline 7. & Omobranchus elegans & $\mathrm{C}$ & + & + \\
\hline 8. & Omobranchus loxozonus & $\mathrm{G}$ & + & + \\
\hline 9. & Entomacrodus caudofasciatus & $\mathrm{C}$ & + & + \\
\hline 10. & Praealticus a. tanegasimae & $\mathrm{C}$ & + & + \\
\hline 11. & Plagiotremus rhinorhynchus & $\mathrm{C}$ & \pm & - \\
\hline 12. & Plagiotremus tapeinosoma & $\mathrm{C}$ & \pm & - \\
\hline 13. & Cirripectes polyzona & $\mathrm{C}$ & - & - \\
\hline 14. & Istiblennius lineatus & $\mathrm{C}$ & - & - \\
\hline 15. & Meiachantus kamoharai & RR & \pm & + \\
\hline 16. & Entomacrodus striatus & RR & \pm & + \\
\hline 17. & Entomacrodus $t$. longicirrus & $\mathrm{RR}$ & \pm & + \\
\hline 18. & Praealticus margaritarius & $\mathrm{RR}$ & \pm & + \\
\hline 19. & Rhabdoblennius ellipes & $\mathrm{RR}$ & \pm & + \\
\hline 20. & Omobranchus fasciolatoceps & $\mathbf{R}$ & + & + \\
\hline 21. & Mimoblennius atrocinctus & $\mathbf{R}$ & \pm & + \\
\hline 22. & Salarias luctuosus & $\mathrm{R}$ & \pm & + \\
\hline 23. & Aspidontus t. taeniatus & $\mathbf{R}$ & \pm & - \\
\hline 24. & Entomacrodus t. thalassinus & $\mathbf{R}$ & $?$ & + \\
\hline 25. & Istiblennius e. edentulus & $\mathrm{R}$ & $?$ & ? \\
\hline 26. & Aspidontus dussumieri & VR & - & - \\
\hline 27. & Meiachanthus a. atrodorsalis & $\mathrm{VR}$ & - & - \\
\hline 28. & Plagiotremus l. laudandus & VR & - & - \\
\hline 29. & Cirripectes castaneus & VR & - & - \\
\hline 30. & Girripectes kuwamurai & VR & - & - \\
\hline 31. & Exallias brevis & VR & - & - \\
\hline 32. & Istiblennius bilitonensis & VR & - & - \\
\hline
\end{tabular}

A: abundant; $\mathrm{C}$ : common; $\mathrm{RR}$ : rather rare; $\mathrm{R}$ : rare; $\mathrm{VR}$ : very rare. In the column of Overwinter, $t$ : maybe survive over winter every year; $t$ : maybe survive over winter only in the case of mild winter; - : maybe not survive over winter every year; ?: not be able to estimate. In the column of Reproduction, + : surely occur or highly probable; - : maybe not occur; ?: not be able to estimate.

in Japanese waters (absent in the Okinawa Islanads) and because they are rather rare everywhere (Masuda et al., 1980).

Ten species (No. 11, 12, 15 to 19, and 21 to 23 in Table 19) may be assigned to Ya-type of Kuwamura. In 3 species belonging to tribe Nemophini (No. 11, 12 and 23 in Table 19), any sign of the reproduction colud not be found in the present study. 
As the observation and collecting efforts on the fishes of Nemophini are rather scarce, however, the possibilities that the reproduction occur seem to be rather high. The populations of these 10 species in the study area may be regarded as unstable and imperfect ones (most of individuals may be recruited there from southern areas by the Kuroshio Current).

Nine species (No. 13, 14, and 26 to 32 in Table 19) may be assigned to A-type of Kuwamura. The fishes of these species are believed to be psudopopulation (almost all individuals may be recruited there from southern areas by the Kuroshio Current). Especially, 7 (No. 26 to 32 in Table 19) of these are regarded as opportunistic immigrants.

The fishes of two rare subspecies (No. 24 and 25 in Table 19) could not be assigned to any group, since the clear distinction from the overwhelming counterpart of each is difficult in the present study.

There are no S-type species of Kuwamura in the blenniids observed. Kuwamura (1980) pointed out that most of S-type species are larger fishes which probably migrate offshore to deep reefs during the cold period. Blenniid species are benthic or suprabenthic (Nemophini) smaller fishes. They may have rigid life style, namely, they may not be able to leave the summer habitat and to migrate to offshore deep reefs during the cold season like S-type larger fishes. The so-called rigid life style is typically shown in the case of $I$. lineatus which is killed by the cold, largely due to living in small, shallow, and highly-placed tide pools.

On the 15 species, the average number of dorsal fin elements and of anal soft

Table 20. Comparison of the average number of dorsal fin elements and anal soft rays in the specimens from Shirahama (S), Okinawajima (O), and from Ishigakijima (I).

\begin{tabular}{|c|c|c|c|c|c|c|c|c|c|}
\hline \multirow{2}{*}{ Species } & \multicolumn{3}{|c|}{ No. of Specimens } & \multicolumn{3}{|c|}{ D Fin Elements } & \multicolumn{3}{|c|}{ A Fin Soft Rays } \\
\hline & $\mathrm{S}$ & $\mathrm{O}$ & I & $\mathrm{S}$ & $\mathrm{O}$ & I & $\mathrm{S}$ & $\mathrm{O}$ & I \\
\hline Omobranchus loxozonus & 26 & 11 & 11 & 32.73 & 33.54 & 34.00 & 22.00 & 22.85 & 23.42 \\
\hline Petroscirtes breviceps & 13 & 1 & - & 30.69 & 30.00 & $\ldots$ & 19.46 & 19.00 & - \\
\hline Plagiotremus tapeinosoma & 1 & 3 & 1 & 45.00 & 45.00 & 45.00 & 31.00 & 31.33 & 31.00 \\
\hline Cirripectes sebae & 2.0 & 8 & - & 26.00 & 26.00 & - & 15.00 & 15.00 & - \\
\hline Entomacrodus caudofasciatus & 14 & 2 & - & 38.00 & 38.00 & 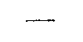 & 16.14 & 16.00 & - \\
\hline Entomacrodus s. stellifer & 34 & $13^{*}$ & - & 28.82 & $29.31 *$ & - & 17.71 & $18.15 *$ & 一 \\
\hline Entomacrodus striatus & 9 & 1 & - & 28.33 & 28.00 & - & 16.89 & 16.00 & - \\
\hline Exallias brevis & 2 & 5 & - & 24.50 & 24.60 & - & 14.00 & 14.00 & - \\
\hline Istiblennius bilitonensis & 1 & 10 & 9 & 33.00 & 32.90 & 33.00 & 20.00 & 20.40 & 20.56 \\
\hline Istiblennius e. edentulus (\$) & 5 & 11 & 11 & 33.00 & 32.82 & 33.09 & 21.80 & 21.27 & 21.36 \\
\hline Istiblennius lineatus & 42 & 20 & 22 & 35.64 & 35.65 & 35.55 & 23.64 & 23.80 & 23.73 \\
\hline Praealticus margaritarius & 9 & 24 & 15 & 30.70 & 31.58 & 31.73 & 19.11 & 19.92 & 20.00 \\
\hline Praealticus a. tanegasimae & 30 & 19 & - & 30.90 & 31.50 & - & 18.83 & 19.16 & - \\
\hline Rhabdoblennius ellipes & 10 & 10 & 9 & 31.70 & 31.80 & 31.78 & 20.70 & 21.30 & 21.00 \\
\hline Salarias luctuosus & 1 & 10 & 14 & 31.00 & 30.80 & 30.57 & 20.00 & 19.70 & 19.57 \\
\hline
\end{tabular}

* after Springer (1967). 
rays are compared among specimens from Shirahama, Okinawajima, and Ishigakijima (Table 20). In 4 species (O. loxozonus, $E$. s. stellifer, $P$. margaritarias, and $P$. a. tanegasimae), an interesting trend that the number of both characters increase in southern (=warmer) localities was noticed. Generally, fin ray counts rather decrease in specimens from warmer localities when local populations in a species are compared (Strasburg, 1955 etc.), in contrast with the present phenomenon. In the case of vertebral number, the same trend has been most commonly observed, but the reverse trend has also been reported in certain instances and in still others, when the mean vertebral numbers are plotted with their respective developmental temperatures, V-shaped curve obtains (Garside, 1966). It is noteworthy that these 4 species are all nearly restricted to southern Japan in their distribution and that 3 of 4 species are estimated to eastablish the stable populations in the study area (an exception is P. margaritarius which is estimated as the unstable population). Another species, Rhabdoblennius ellipes, is also restricted to southern Japan in their distribution. In this species, however, such trend was exceptionally not noticed among specimens from above noted three localities in the present study.

\section{Acknowledgements}

The Seto Marine Biological Laboratory of Kyoto University provided the facilities for my field study. I am grateful to Professor Tamotsu Iwai of Kyoto University, Mr. Chuichi Araga of the Seto Marine Biological Laboratory, Kyoto University, and Dr. Izumi Nakamura of the Fisheries Research Station, Kyoto University, for their helpful suggestions and critical reading of the manuscript.

\section{References}

Aoyagi, H. 1941. Note on the fishes of the Ryukyu Islands. V. The marine fishes of Miyako Islands. Trans. Biogeogr. Soc. Japan, 3: 287-301.

-1954. Studies on the coral fishes of the Riu-Kiu Islands IX. Blenniidae (I). Zool. Mag., 63: 278-287.

1955. Studies on the coral fishes of the Riu-Kiu Islands X. Blenniidae (2). Zool. Mag., 64: $76-83$.

Araga, C., \& H. Tanase. 1966. Inshore fishes of Wakayama Prefecture. Rep. Jap. Ass. Nat. Conservation, 27: 81-95. (In Japanese)

- \& 1968. Further record of winter fish stranding in the vicinity of Seto. Publ. Seto Mar. Biol. Lab., 16: 207-218.

Arai, R., \& T. Abe. 1970. The sea fishes of the Tsushima Islands, Japan. Mem. Natn. Sci. Mus., 3: 83-100.

- \& H. Ida. 1975. The sea fishes of Yakushima and Tanegashima Islands, southern Kyushu, Japan. Mem. Natn. Sci. Mus., 8: 183-198.

Bath, H. 1970. Vergleichend-morphologische, taxonomische und zoogeographische Untersuchungen an den Schleimfischarten Blennius cristatus, crinitus und nuchifilis (Pisces: Blennioidae: Blenniidae). Senck. Biol., 51: 187-306.

Chapman, W.M. 1951. Family Blenniidae. In de Beaufort, L.F., Fishes of the Indo-Australian Archipelago, 9: 243-383. E. J. Brill, Leiden.

Dotsu, Y., \& M. Nakamura. 1976. The fishes of Tsushima Island. Nagasaki-ken Seibutsu-Gakkai: 265-287. (In Japanese)

- , \& I. Tomiyama. 1976. The marine fishes from Saikai National Park of Japan. Bull. Fac. Fish., Nagasaki Univ., 23: 1-42. (In Japanese) 
Fowler, H.W. 1946. A collection of fishes obtained in the Riu Kiu Islands by Captain Ernest R. Tinkham A. U. S. Proc. Acad. Nat. Sci. Philad., 98: 123-218.

Fukao, R. 1984. Review of Japanese fishes of the genus Cirripectes (Pisces: Blenniidae) with description of a new species. Japan. J. Ichthyol., 31 : 105-121.

Garside, E.T. 1966. Development rate and vertebral number in salmonids. J. Fish. Res. Bd. Can., 23: 1537-1551.

Honma, Y. 1977. A list of the fishes obtained from Sado Strait, whose specimens are deposited in the Matsugasaki Middle School, Sado Island of the Japan Sea. Bull. Niigata Pref. Biol. Soc. Educ., 12: 31-38. (In Japanese)

드, \& C. Sugihara. 1963. A revised list of the blennioid and ophidioid fishes of the suborder Blenniina obtained from the waters of Sado Island, including the area of Yamagata Prefecture, Sea of Japan. Bull. Sado Mus., 11:5-9. (In Japanese)

Hubbs, C.L., \& K.F. Lagler. 1958. Fishes of the Great Lakes Region. Bull. Cranbrook Inst. Sci., 26: $1-213$.

Ichthyological Society of Japan, 1981. Dictionary of Japanese fish names and their foreign equivalents. vii +834 pp. Sanseido, Tokyo.

Jordan, D.S., S. Tanaka \& J.O. Snyder. 1913. A catalogue of the fishes of Japan. J. Coll. Sci., Tokyo Imp. Univ., 33: 1-497.

Kamohara, T. 1950. Description of the fishes from the Provinces of Tosa and Kishu, Japan. 3+288 $+5+48+27$ pp. Kochi Society of Education, Kochi.

-1957a. Notes on twenty additions to the marine fish fauna of Prov. Tosa, Japan, including one new genus (Family Peristediidae). Res. Rep. Kochi Univ., 6: 1-6.

- 1957b. List of fishes from Amami-Oshima and adjacent regions, Kagoshima Prefecture, Japan. Rep. Usa Mar. Biol. Stat., 4: 1-65.

- 1958a. The fishes of Urado Bay, Kochi Prefecture. Res. Rep. Kochi Univ., 7: 1-11. (In Japanese)

- 1958b. A calalogue of fishes of Kochi Prefecture (Province Tosa), Japan. Rep. Usa Mar. Biol. Stat., 5: 1-76.

- 1964. Revised catalogue of fishes of Kochi Prefecture, Japan. Rep. Usa Mar. Biol. Stat, 11: 1-99.

- \& T. Yamakawa. 1965. Fishes from Amami-Oshima and adjacent regions. Rep. Usa Mar. Biol. Stat., 12: 1-27.

$\longrightarrow$ \& 1968 . Additional records of marine fishes from Amami (II). Rep. Usa Mar. Biol. Stat., 15: 1-17.

Katayama, M. 1940. A catalogue of the fishes of Toyama Bay. Toyama Hakubutsu Gakkai-shi, 3: 1-28. (In Japanese)

- 1941. A new blennoid fish from Toyama Bay. Zool. Mag., 53: 591-592. , \& Y. Fujioka. 1958. Fishes of Oosima-gun, Yamaguti Prefecture. Bull. Fac. Agr. Yamaguti Univ., 9: 1147-1168. (In Japanese)

- \& H. Ikeda. 1973. Omobranchus wekii from the Inland Sea. Yamaguchi-ken no Shizen, $3(8), 28: 7-7$. (In Japanese)

Kato, G. 1956. A catalogue of the marine fishes of the Japan Sea. Bull. Japan Sea Reg. Fish. Res. Lab., Fish. Agency, 4: 311-331. (In Japanese)

Kuwamura, T. 1976. Seasonal occurrence of fishes in the interstice of shrub corals on the rocky reef of Shirahama, Japan. Nankiseibutu: Nanki Biol. Soc., 18: 15-22. (In Japanese)

-1980. Seasonal occurrence of fishes at inshore rocky reefs in Shirahama, southern Japan. Japan. J. Ichthyol., 27: 243-248. (In Japanese)

-1981. Mimicry of the cleaner wrasse Labroides dimidiatus by the blennies Aspidontus taeniatus and Plagiotremus rhinorhynchos. Nankiseibutu: Nanki Biol. Soc., 23: 61-70. (In Japanese)

-., R. Fukao, T. Nakabo, M. Nishida, T. Yanagisawa \& Y. Yanagisawa, 1983. Inshore fishes of the Ogasawara (Bonin) Islands, Japan. Galaxea, 2: 83-94.

Lee, S.-C. 1979. New record of two blennoid fishes, Exallias brevis and Cirripectes fuscoguttatus from waters of Taiwan. Bull. Inst. Zool., Acad. Sinica, 18: 55-57. 
Masuda, H., C. Araga \& T. Yoshino. 1975. Coastal fishes of southern Japan. 379 pp., Tokai Univ. Press, Tokyo.

Tokai Univ. Press, Tokyo.

Matsubara, K. 1955. Fish morphology and hierarchy. Part 1. xi+789 pp. Ishizaki Shoten, Tokyo. (In Japanese)

Miura, N., Y. Dotsu \& H. Iwamoto. 1973. Tide-pool fishes of Mejima Island, Danjo Islands: in Fauna and flora of Danjo Is. Special Pub., Nagasaki Biol. Soc.: 59-72. (In Japanese)

Okada, Y. 1955. Fishes of Japan. Illustrations and descriptions of fishes of Japan. 434 pp. Maruzen Co., Ltd., Tokyo.

Regan, C.T. 1909. A collection of fishes made by Dr. G.W. Andrews, F.R.S., at Christmas Island. Proc. Zool. Soc. London, 1909: 403-406.

Schmidt, P.J. 1930. Fishes of the Riu-Kiu Islands. Trans. Pacif. Comm. Acad. Sci. USSR, 1: $19-156$.

. 1931. Fishes of Japan, collected in 1901. Trans. Pacif. Comm. Acad. Sci. USSR, 2: $1-176$.

Schultz, L.P., \& W.M. Chapman. 1960. Subfamily Salarinae. In Fishes of the Marshall and Marianas Islands. U.S. Nat. Mus. Bull., 202: 302-372.

Shiogaki, M., \& Y. Dotsu. 1973. Fishes collected from the coastal waters of Nomozaki near Nagasaki. Bull. Fac. Fish., Nagasaki Univ., 35: 11-39. (In Japanese)

-, Y. Natsukari \& Y. Dotsu. 1971. The fishes from a site proposed for the marine park of the Goto Islands. Nagasaki-ken Kaichyu-koen Gakujutsu-chosa Hokokusho,: 51-70. (In Japanese)

Smith, R.L. 1974. On the biology of Blennius cristatus with special reference to anal fin morphology. Bull. Mar. Sci., 24: 595-605.

Smith-Vaniz, W.F. 1976. The saber-toothed blennies, tribe Nemophini (Pisces: Blenniidae). Acad. Nat. Sci. Philad., Monogr., 19: i-vii, 1-196.

—, \& V.G. Springer. 1971. Synopsis of the tribe Salariini, with description of five new genera and three new species (Pisces: Blenniidae). Smithson. Cont. Zool., 73: 1-72.

Springer, V.G. 1967. Revision of the circumtropical shore-fish genus Entomacrodus. Proc. U.S. Nat. Mus., 122: 1-150.

- 1971. Revision of the fish genus Ecsenius (Blenniidae, Blenniinae, Salariini). Smithson. Cont. Zool., 72: 1-74.

-1972. Additions to revision of the blenniid fish genera Ecsenius and Entomacrodus, with description of three new species of Ecsenius. Smithson. Cont. Zool., 134: 1-13.

- \& M.F. Gomon. 1975. Revision of the blenniid fish genus Omobranchus with descriptions of three new species and notes on other species of the tribe Omobranchini. Smithson. Cont. Zool., 177: i-iii, 1-135.

—_, \& A.E. Spreitzer. 1978. Five new species and a new genus of Indian Ocean blenniid fishes, tribe Salarini, with a key to genera of the tribe. Smithson. Cont. Zool., 268: 1-20.

Strasburg, D.W. 1955. North-south differentiation of blenniid fishes in the central Pacific. Pacif. Sci, 9: 297-303.

- \& L.P. Schultz. 1953. The blenniid fish genera Cirripecius and Exallias with description of two new species from the tropical Pacific. J. Wash. Acad. Sci., 43: 128-135.

Suzuki, K., \& K. Kobayashi. 1972. The coastal fish fama of the southern and western (Uchiura Bay) Izu, with consideration on the fauna. Shizuoka-ken Kaichu-koen Gakujutsu-chosa Hokokusho, pp. 27-50. (In Japanese)

Tatara, K., R. Kitamori, K. Nagata, S. Mito, T. Hayashi \& S. Kudo. 1965. A catalogue of fishes in Seto Inland Sea and adjacent waters, with a list of molluscan. Naikai Reg. Fish. Res. Lab., Publ., C. (3): 77-123. (In Japanese)

Ueno, T. 1971. List of the marine fishes from the waters of Hokkaido and its adjacent regions. Sci. Rep. Hokkaido Fish. Exp. Stat., 13:61-102. (In Japanese)

Ui, N. 1929. Fishes of Kishu, Wakayama Prefecture. $284+45$ pp. Takahashi Nanki-sha, Osaka. (In Japanese) 
Yamakawa, T. 1979. Studies of the fish fauna around the Nansei Islands, Japan. 1. Check list of fishes collected by Toshiji Kamohara and Takeshi Yamakawa from 1954 to 1971. Rep. Usa Mar. Biol. Inst., Supplement to No. 1: 1-47.

Yoshino, T., \& S. Nishijima. 1981. A list of fishes found around Sesoko Island, Okinawa. Sesoko Mar. Sci. Lab. Tech. Rep., 8: 19-87.

- - \& S. Shinohara. 1975. Catalogue of fishes of the Ryukyu Islands. Bull. Sciences \& Engineering Div., Univ. of the Ryukyus (Math. \& Nat. Sci. 20): 61-118. (In Japanese)

Zama, A., \& K. Fujita. 1977. An annotated list of fishes from the Ogasawara Islands. J. Tokyo Univ. Fish., 63: 87-138. (In Japanese)

_. $\quad$ \& F. Yasuda. 1979. An annotated list of fishes from the Ogasawara Islands - Supplement I, with zoogeographical notes on the fish fauna. J. Tokyo Univ. Fish., 65: 139-163. 